\title{
Determination of the $\delta^{15} \mathrm{~N}$ of Nitrate in Solids; RSIL Lab Code 2894
}

Chapter 12 of

Section C, Stable Isotope-Ratio Methods

Book 10, Methods of the Reston Stable Isotope Laboratory

Techniques and Methods 10-C12 
This page left blank intentionally. 


\section{Determination of the $\delta^{15} \mathrm{~N}$ of Nitrate in Solids; RSIL Lab Code 2894}

By Tyler B. Coplen, Haiping Qi, Kinga Révész, Karen Casciotti, and Janet E. Hannon

Chapter 12 of

Section C, Stable Isotope-Ratio Methods Book 10, Methods of the Reston Stable Isotope Laboratory

Edited by Kinga Révész and Tyler B. Coplen

Techniques and Methods 10-C12 


\title{
U.S. Department of the Interior KEN SALAZAR, Secretary
}

\author{
U.S. Geological Survey \\ Marcia K. McNutt, Director
}

\author{
U.S. Geological Survey, Reston, Virginia: 2012 \\ Version 1.0, 2007 \\ Version 1.1, 2012
}

For sale by U.S. Geological Survey, Information Services

Box 25286, Denver Federal Center

Denver, CO 80225

For more information about the USGS and its products:

Telephone: 1-888-ASK-USGS

World Wide Web: http://www.usgs.gov/

Any use of trade, product, or firm names in this publication is for descriptive purposes only and does not imply endorsement by the U.S. Government.

Although this report is in the public domain, permission must be secured from the individual copyright owners to reproduce any copyrighted material contained within this report.

\footnotetext{
Suggested citation:

Coplen, T.B., Qi, Haiping, Révész, Kinga, Casciotti, Karen, and Hannon, J.E., 2012, Determination of the $\delta^{15} \mathrm{~N}$ of nitrate in solids; RSIL lab code 2894, chap. 12 of Stable isotope-ratio methods, sec. C of Révész, Kinga, and Coplen, T.B. eds., Methods of the Reston Stable Isotope Laboratory (slightly revised from version 1.0 released in 2007): U.S. Geological Survey Techniques and Methods, book 10, 35 p., available only online at http://pubs.usgs.gov/tm/2006/tm10c12/. (Supersedes version 1.0 released in 2007.)
} 


\section{Foreword}

The Reston Stable Isotope Laboratory (RSIL) provides stable isotope analyses on a routine basis for a large user community within the U.S. Geological Survey (USGS) and elsewhere. The RSIL also serves the USGS National Research Program (NRP) through its project on Stable Isotope Fractionation in Hydrologic Processes. The NRP conducts basic and problem-oriented hydrologic research in support of the mission of the USGS. The stable isotope project conducts research on the use of isotope-ratio measurements in studies of water resources and environmental quality. One objective of this project is to develop new techniques for isotopic analysis of hydrogen, nitrogen, oxygen, carbon, and sulfur in environmental samples. New analytical techniques expand the range of tools available for studying the movement of those elements in hydrologic and biogeochemical systems. Another objective of the project is to test new applications of isotope measurements in specific field settings. Field studies of isotope behavior have contributed to understanding water-supply sustainability, groundwater/surface-water interactions, paleoclimate history, biologic cycling of nutrients, groundwater contamination, and natural remediation. This project also contributes to the improvement of measurement science and the development of isotope databases.

Book 10 of the Techniques and Methods Series of the USGS contains detailed descriptions of methods of the RSIL, including routine analytical methods called standard operating procedures (SOPs), along with safety guidelines, maintenance procedures, and other information about the operation of the RSIL. Section C of book 10 contains the SOPs for a variety of methods to measure stable isotope ratios, each of which constitutes a chapter. Each chapter is limited to a narrow field of subject matter to permit flexibility in revision as the need arises.

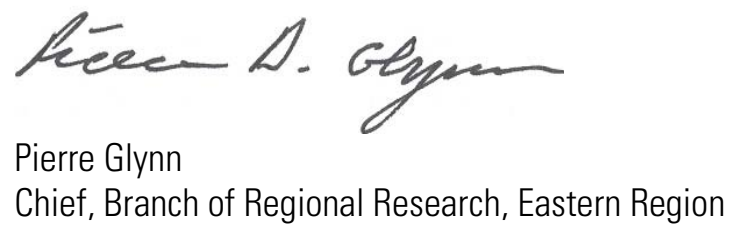


This page left blank intentionally. 


\section{Contents}

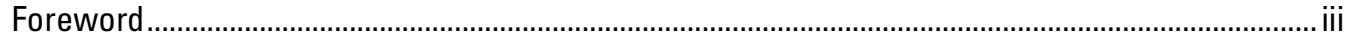

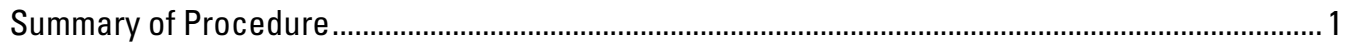

Reporting Units and Operational Range ....................................................................................... 1

Reference Materials and Documentation .............................................................................. 2

Reference Materials Used, Storage Requirements, and Shelf Life................................... 2

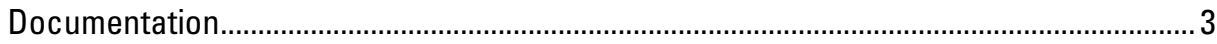

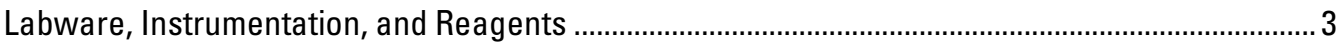

Sample Collection, Preparation, Analysis, Retention Times, and Disposal...................................... 5

Sample Containers, Preservation, and Handling Requirements ........................................ 5

Sample Preparation and Time Requirements ...................................................................... 6

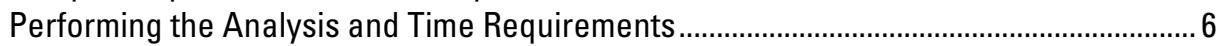

Problematic Samples.................................................................................................

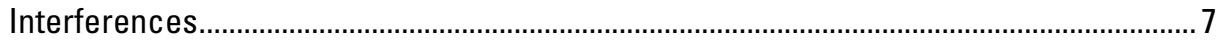

Troubleshooting and Bench Notes....................................................................................... 8

Maintenance and Maintenance Records .................................................................... 8

Sample Retention Time and Disposal ................................................................................ 8

Data Acquisition, Processing, Evaluation, Quality Control, and Quality Assurance ....................... 8

Laboratory Information Management System for Light Stable Isotope (LIMS-LSI) ........... 8

Quality Control (OC) Samples..........................................................................................

Acceptance Criteria for All QC Samples ………………...............................................

Corrective Action Requirements............................................................................................ 9

Responsible Parties for All OC/QA Functions for Procedures Covered in RSIL SOPs .... 10

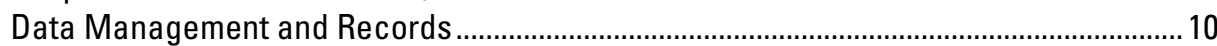

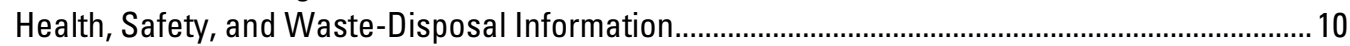

Applicable Health and (or) Safety Issues..................................................................... 10

Personal Protection ............................................................................................... 10

Electrical Hazards.................................................................................................... 10

Chemical Hazards ..................................................................................................... 10

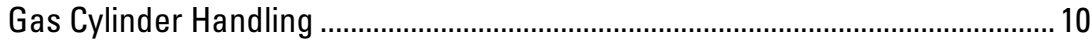

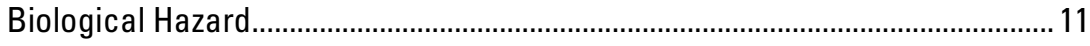

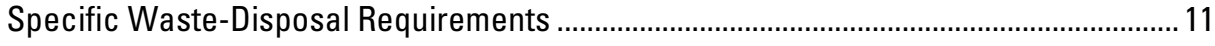

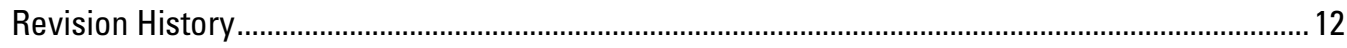

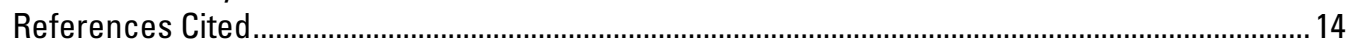

Appendix A. Step-by-Step Procedure to Log-In Samples to LIMS-LSI.......................................... 15

Appendix B. Step-by-Step Procedure to Print a Template and a Samples-to-Be-Analyzed

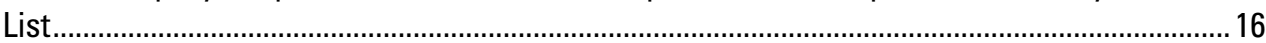

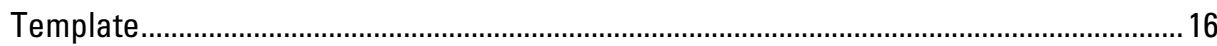

Appendix C. Step-by-Step Preparation Procedure for Nitrogen Isotopic Analysis of Nitrate

by Bacterial Denitrific ation...................................................................................................... 18

Making the Plates ………........................................................................................... 18

Preparing the Tryptic Soy Broth (TSB) ......................................................................... 18

Testing Bacteria for Incomplete Conversion of Nitrate .................................................... 18

Harvesting the Bacteria—Concentrating Culture by Centrifugation ................................. 20

Adding Concentrated Cell Culture to Sample Vial and Purging Headspace and

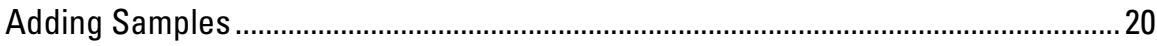

Appendix D. Step-by-Step Procedure to Add Sample Information to Sequence Table ................... 31

Appendix E. Step-by-Step Procedure to Transfer Data to LIMS-LSI, to Transfer Data to

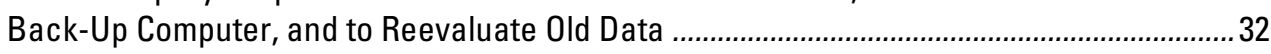

Appendix F. Step-by-Step Procedure to Determine and Apply Correction Factors and

Evaluate Data 


\section{Figures}

1. Schematic of modified Finnigan MAT (now Thermo Scientific) GasBench 2

inlet system...

2. Schematic of a continuous flow isotope-ratio mass spectrometer (CF-IRMS)

(modified from Clark and Fritz, 1997).

B-1. Sample list generated by LIMS...................................................................................16

C-1. Tryptic soy broth (TSB), with $\mathrm{KNO}_{3^{\prime}}$ prepared, mixed in 9-L bottle (yellow

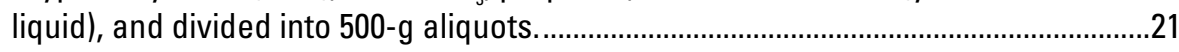

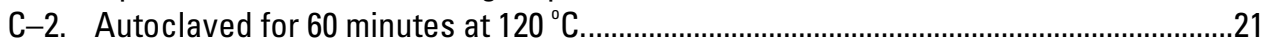

C-3. Top view of 580-mL bottles with media ready to be autoclaved. .................................22

C-4. Tryptic Soy broth (TSB) without $\mathrm{KNO}_{3}$, prepared with $100-\mathrm{mL}$ aliquots in

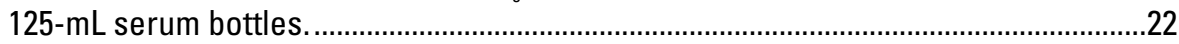

C-5. Selecting a separate colony from the plate using a sterile flamed loop......................23

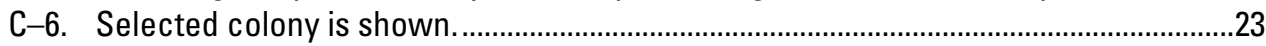

C-7. Selected colony transferred to labeled tube containing $5 \mathrm{~mL}$ of TSB.........................24

C-8. Shaker showing $5 \mathrm{~mL}$ of culture before injection and showing previously prepared 580-mL bottles injected with bacteria......................................................24

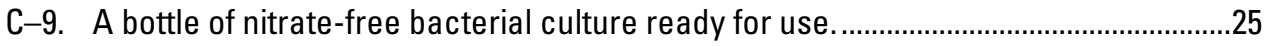

C-10. Centrifuge with four 250-mL bottles........................................................................25

C-11. Twenty-milliliter sample vial containing $3 \mathrm{~mL}$ of concentrated cell culture................26

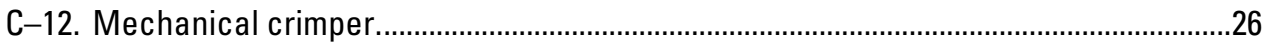

C-13. PTFE/Aluminum-lined septa with aluminum crimps...................................................27

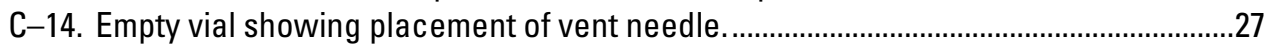

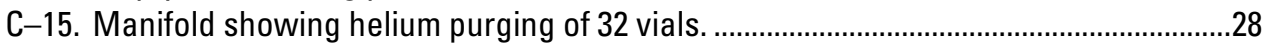

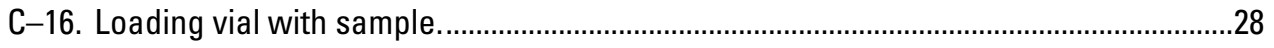

C-17. Aluminum tray with inverted sample vials. ..............................................................29

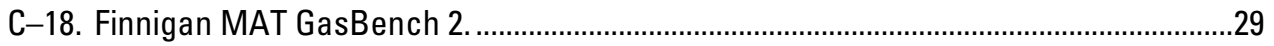

C-19. Sample tray with 32 vials and a $1 / 4$-inch-thick aluminum plate to secure vials.............30 


\section{Conversion Factors}

\begin{tabular}{lll}
\hline Multiply & By & To Obtain \\
\hline millimeter $(\mathrm{mm})$ & Length & \\
centimeter $(\mathrm{cm})$ & 0.03937 & inch \\
meter $(\mathrm{m})$ & 0.3937 & inch \\
\hline & 3.281 & foot \\
\hline microliter $(\mu \mathrm{L})$ & Volume & \\
milliliter $(\mathrm{mL})$ & $0.0610210^{-3}$ & cubic inch \\
cubic centimeter $\left(\mathrm{cm}^{3}\right)$ & 0.06102 & cubic inch \\
\hline & 0.06102 & cubic inch \\
\hline nanogram $(\mathrm{ng})=10^{-3} \mu \mathrm{g}$ & Mass & \\
microgram $(\mu \mathrm{g})=10^{-3} \mathrm{mg}$ & $3.527 \times 10^{-11}$ & ounce \\
milligram $(\mathrm{mg})=10^{-3} \mathrm{~g}$ & $3.527 \times 10^{-8}$ & ounce \\
gram $(\mathrm{g})=10^{-3}(\mathrm{~kg})$ & $3.527 \times 10^{-5}$ & ounce \\
kilogram $=10^{3} \mathrm{~g} ; 10^{6} \mathrm{mg} ; 10^{9} \mu \mathrm{g} ; 10^{12} \mathrm{ng}$ & 2.205 & ounce \\
\hline & $3.527 \times 10^{-2}$ & pound \\
\hline gram per cubic centimeter $\left(\mathrm{g} / \mathrm{cm}^{3}\right)$ & 0.5780 & \\
\hline Celsius $\left({ }^{\circ} \mathrm{C}\right)$ & Temperature & ounce per cubic inch \\
\hline & ${ }^{\circ} \mathrm{F}=9 / 5\left({ }^{\circ} \mathrm{C}\right)+32$ & Fahrenheit $\left({ }^{\circ} \mathrm{F}\right)$ \\
\hline
\end{tabular}




\section{Acronyms and Abbreviations}

$\begin{array}{ll}\text { ANSI } & \text { American National Standards Institute } \\ \text { CF-IRMS } & \text { continuous flow isotope-ratio mass spectrometer } \\ \text { cm } & \text { centimeter } \\ \text { DIW } & \text { deionized water } \\ \text { g } & \text { gram } \\ \text { h } & \text { hour } \\ \text { HDPE } & \text { high-density polyethylene } \\ \text { IRMS } & \text { isotope-ratio mass spectrometer } \\ \text { LIMS-LSI } & \text { Laboratory Information Management System for Light Stable Isotopes } \\ \text { MSDS } & \text { Material Safety Data Sheets } \\ \text { mg } & \text { milligram } \\ \text { mg/kg } & \text { milligrams per kilogram } \\ \text { min } & \text { minute } \\ \text { mL } & \text { milliliter } \\ \text { mL/min } & \text { milliliter per minute } \\ \text { mm } & \text { millimeter } \\ \text { mm/s } & \text { millimeter per second } \\ \text { nmol } & \text { nanomole } \\ \text { NFPA } & \text { National Fire Protection Association } \\ \text { NWQL } & \text { National Water Quality Laboratory (USGS) } \\ \text { per mil, \%o } & \text { one part in one thousand parts, with value 10 } \\ \text { pF } & \text { picofarad } \\ \text { QA } & \text { quality assurance } \\ \text { QC } & \text { quality control } \\ \text { QC/QA } & \text { quality control/quality assurance } \\ \text { RSIL } & \text { Reston Stable Isotope Laboratory } \\ \text { SOP } & \text { standard operating procedure } \\ \text { std } & \text { international measurement standard } \\ \text { TSA } & \text { tryptic soy agar } \\ \text { TSB } & \text { tryptic soy broth } \\ \text { USGS } & \text { U.S. Geological Survey } \\ \mu \text { g } & \text { microgram } \\ \mu \text { M } & \text { micromolar } \\ & \end{array}$

\section{Symbols}

$\begin{array}{ll}\Omega & \text { ohm } \\ < & \text { less than } \\ > & \text { greater than } \\ \leq & \text { less than or equal to }\end{array}$




\title{
Determination of the $\delta^{15} \mathrm{~N}$ of Nitrate in Solids; RSIL Lab Code 2894
}

\author{
By Tyler B. Coplen', Haiping Qi', Kinga Révész', Karen Casciotti', and Janet E. Hannon'
}

\section{Summary of Procedure}

The purpose of the Reston Stable Isotope Laboratory (RSIL) lab code 2894 is to determine the $\delta^{15} \mathrm{~N}$ of nitrate $\left(\mathrm{NO}_{3}{ }^{-}\right)$in solids. The nitrate fraction of the nitrogen species is dissolved by water (called leaching) and can be analyzed by the bacterial method covered in RSIL lab code 2899. After leaching, the $\delta^{15} \mathrm{~N}$ of the dissolved $\mathrm{NO}_{3}^{-}$is analyzed by conversion of the $\mathrm{NO}_{3}^{-}$to nitrous oxide $\left(\mathrm{N}_{2} \mathrm{O}\right)$, which serves as the analyte for mass spectrometry. A culture of denitrifying bacteria is used in the enzymatic conversion of $\mathrm{NO}_{3}^{-}$to $\mathrm{N}_{2} \mathrm{O}$, which follows the pathway shown in equation 1 :

$$
\mathrm{NO}_{3}^{-} \rightarrow \mathrm{NO}_{2}^{-} \rightarrow \mathrm{NO} \rightarrow 1 / 2 \mathrm{~N}_{2} \mathrm{O}
$$

Because the bacteria Pseudomonas aureofaciens lack $\mathrm{N}_{2} \mathrm{O}$ reductive activity, the reaction stops at $\mathrm{N}_{2} \mathrm{O}$, unlike the typical denitrification reaction that goes to $\mathrm{N}_{2}$. After several hours, the conversion is complete, and the $\mathrm{N}_{2} \mathrm{O}$ is extracted from the vial, separated from volatile organic vapor and water vapor by an automated $-65{ }^{\circ} \mathrm{C}$ isopropanol-slush trap, a Nafion drier, a $\mathrm{CO}_{2}$ and water removal unit (Costech \#021020 carbon dioxide absorbent with $\left.\mathrm{Mg}\left(\mathrm{ClO}_{4}\right)_{2}\right)$, and trapped in a small-volume trap immersed in liquid nitrogen with a modified Finnigan MAT (now Thermo Scientific) GasBench 2 introduction system. After the $\mathrm{N}_{2} \mathrm{O}$ is released, it is further purified by gas chromatography before introduction to the isotoperatio mass spectrometer (IRMS). The IRMS is a Thermo Scientific Delta V Plus continuous flow IRMS (CF-IRMS). It has a universal triple collector, consisting of two wide cups with a narrow cup in the middle; it is capable of simultaneously measuring mass/charge $(\mathrm{m} / \mathrm{z})$ of the $\mathrm{N}_{2} \mathrm{O}$ molecule 44 , 45, and 46. The ion beams from these $m / z$ values are as follows: $m / z=44=\mathrm{N}_{2} \mathrm{O}={ }^{14} \mathrm{~N}^{14} \mathrm{~N}^{26} \mathrm{O} ; \mathrm{m} / \mathrm{z}=45=\mathrm{N}_{2} \mathrm{O}=$ ${ }^{14} \mathrm{~N}^{15} \mathrm{~N}^{16} \mathrm{O}$ or ${ }^{14} \mathrm{~N}^{14} \mathrm{~N}^{17} \mathrm{O} ; \mathrm{m} / \mathrm{z}=46=\mathrm{N}_{2} \mathrm{O}={ }^{14} \mathrm{~N}^{14} \mathrm{~N}^{18} \mathrm{O}$. The ${ }^{17} \mathrm{O}$ contributions to the $\mathrm{m} / \mathrm{z} 44$ and $\mathrm{m} / \mathrm{z} 45$ ion beams are accounted for before $\delta^{15} \mathrm{~N}$ values are reported.

\section{Reporting Units and Operational Range}

Variations in stable isotope ratios typically are small. Stable isotope ratios commonly are measured and expressed as the relative difference in the ratio of the number of the less abundant isotope (usually the heavy isotope) to the number of the more abundant isotope (usually the light isotope) of a sample with respect to the measurement standard, std (Coplen, 2011). This relative difference is designated $\delta$ E, which is a shortened form of $\delta\left({ }^{i} \mathrm{E} / \mathrm{E}\right)$ or $\delta\left({ }^{i} \mathrm{E}\right)$, and is defined according to equation 2 (Coplen, 2011):

$$
\delta^{i} \mathrm{E}=\delta\left({ }^{i} \mathrm{E}\right)=\delta\left({ }^{i} \mathrm{E} /{ }^{j} \mathrm{E}\right)=\frac{N\left({ }^{i} \mathrm{E}\right)_{\mathrm{P}} / N\left({ }^{j} \mathrm{E}\right)_{\mathrm{P}}-N\left({ }^{i} \mathrm{E}\right)_{\text {std }} / N\left({ }^{j} \mathrm{E}\right)_{\text {std }}}{N\left({ }^{i} \mathrm{E}\right)_{\text {std }} / N\left({ }^{j} \mathrm{E}\right)_{\text {std }}}
$$

\footnotetext{
${ }^{1}$ U.S. Geological Survey, Reston Stable Isotope Laboratory, Reston, Virginia 20192

${ }^{2}$ Stanford University, Department of Environmental Earth System Science, 397 Panama Mall, California 943052210
} 
where $N\left({ }^{i} \mathrm{E}\right)_{\mathrm{P}}$ and $N\left({ }^{j} \mathrm{E}\right)_{\mathrm{p}}$ are the numbers of the two isotopes ${ }^{i} \mathrm{E}$ and ${ }^{j} \mathrm{E}$ of element $\mathrm{E}$ in specimen $\mathrm{P}$ and equivalent parameters follow for the international measurement standard, "std." A positive $\delta^{i} \mathrm{E}$ value indicates that the specimen is enriched in the heavy isotope, ${ }^{i} \mathrm{E}$, relative to the std. A negative $\delta^{i} \mathrm{E}$ value indicates that the specimen is depleted in the heavy isotope, E, relative to the std. For stable nitrogen isotope-amount ratios, $\delta^{15} \mathrm{~N}$ is defined as follows:

$$
\delta^{15} \mathrm{~N}=\delta\left({ }^{15} \mathrm{~N}\right)=\delta\left({ }^{15} \mathrm{~N} /{ }^{14} \mathrm{~N}\right)=\frac{N\left({ }^{15} \mathrm{~N}\right)_{\mathrm{P}} / N\left({ }^{14} \mathrm{~N}\right)_{\mathrm{P}}-N\left({ }^{15} \mathrm{~N}\right)_{\mathrm{std}} / N\left({ }^{14} \mathrm{~N}\right)_{\mathrm{std}}}{N\left({ }^{15} \mathrm{~N}\right)_{\mathrm{std}} / N\left({ }^{14} \mathrm{~N}\right)_{\mathrm{std}}}
$$

The primary reference material for relative nitrogen isotope-ratio measurements $\left(\delta^{15} \mathrm{~N}\right)$ is atmospheric nitrogen gas $\left(\mathrm{N}_{2}\right)$, which is widespread and homogeneous and, by convention, has a $\delta^{15} \mathrm{~N}$ consensus value of 0 (Mariotti, 1983). By interspersing internationally distributed isotopic reference materials with accepted $\delta$ values among unknown samples, the $\delta$ values can be determined on normalized $\delta^{15} \mathrm{~N}$ scales. The $\delta^{15} \mathrm{~N}$ scale is determined by analyzing reference materials IAEA-N-1 and USGS32, which have an assigned values of +0.43 and $+180 \%$ o, respectively (Böhlke and Coplen, 1995). The $\delta^{15} \mathrm{~N}$ measurements are made with a CF-IRMS, which alternately measures the isotope-amount ratios of the sample $\mathrm{N}_{2} \mathrm{O}$ gas and one or more injections of the "working reference" $\mathrm{N}_{2} \mathrm{O}$ gas. Values of $\delta^{15} \mathrm{~N}$ typically are reported in parts per thousand (\%).

The system was tested by analyzing pure inorganic samples (potassium and sodium nitrates). The routine analysis requires $0.28 \mu \mathrm{g} \mathrm{N}$; however, the system is capable of analyzing samples as small as 0.14 microgram $(\mu \mathrm{g})$ nitrogen in one sample aliquot. Therefore, the range of nitrogen concentration needed for this analyses is more than 0.03 milligrams per kilogram $(\mathrm{mg} / \mathrm{kg}) \mathrm{NO}_{3}^{-}$as nitrogen, compared with less than $1000 \mathrm{mg} / \mathrm{kg} \mathrm{NO}_{3}^{-}$covered in RSIL Lab code 2893 (Révész and Qi, 2006), where $\delta^{15} \mathrm{~N}$ of total nitrogen in solids is determined by elemental analyzer. The $\delta^{15} \mathrm{~N}$ values of reference materials ranged from approximately -1.8 to $+180 \%$, which covers much of the range of isotopic composition of natural samples. The precision and accuracy of the results were acceptable, and no memory effect was observed. The uncertainties of precision and accuracy were less than or equal to $0.25 \%$ for the $\delta^{15} \mathrm{~N}$ measurement.

\section{Reference Materials and Documentation}

\section{Reference Materials Used, Storage Requirements, and Shelf Life}

Internationally distributed reference materials used in the RSIL are solid nitrogen-bearing materials, which have wide range of isotopic composition. In the measurement of $\delta^{15} \mathrm{~N}$, USGS34 potassium nitrate $\left(\mathrm{KNO}_{3}\right)$ with a $\delta^{15} \mathrm{~N}$ value of $-1.8 \%$ (Böhlke and others, 2003) and a USGS32 $\mathrm{KNO}_{3}$ with a $\delta^{15} \mathrm{~N}$ value of $+180 \%$ o (Böhlke and others, 1993) are used.

All of these reference materials are stored in the RSIL at room temperature in glass bottles capped with Teflon-coated or cone-shaped caps to keep moisture out. Their shelf life is indefinite.

Primary stocks of $20-\mathrm{mM}$ reference nitrates are prepared by dissolving solid references, and they are stored in a refrigerator at $5{ }^{\circ} \mathrm{C}$. The 20 -micromolar $(\mu \mathrm{M})$ secondary working stock solutions are prepared every 1 to 2 months by diluting the primary stocks. These $20-\mu \mathrm{M}$ working stocks are also stored in a refrigerator between uses and are analyzed along with the samples in amounts identical to that of the samples analyzed in a particular batch. 


\section{Documentation}

All calibration results are stored in the Laboratory Information Management System for Light Stable Isotopes (LIMS-LSI) (Coplen, 2000) under sample identifiers N-7 and N-34.

\section{Labware, Instrumentation, and Reagents}

Preparatory labware and apparatus include beakers, watch glasses, 580-milliliters (mL) glass serum bottles, Petri dishes, flasks, a torch, sterile plastic test tubes, spreading loop, a laboratory shaker, freezers, a refrigerator, an autoclave, and a tabletop centrifuge.

The analytical apparatus consists of three different units: (1) an automated sample extraction and analysis system, (2) IRMS, and (3) computer software. The automated sample extraction and analysis system is a modified and improved version (Coplen and others, 2004) of the Finnigan MAT GasBench 2 (fig. 1), first described by Sigman and others (2001) and by Casciotti and others (2002).

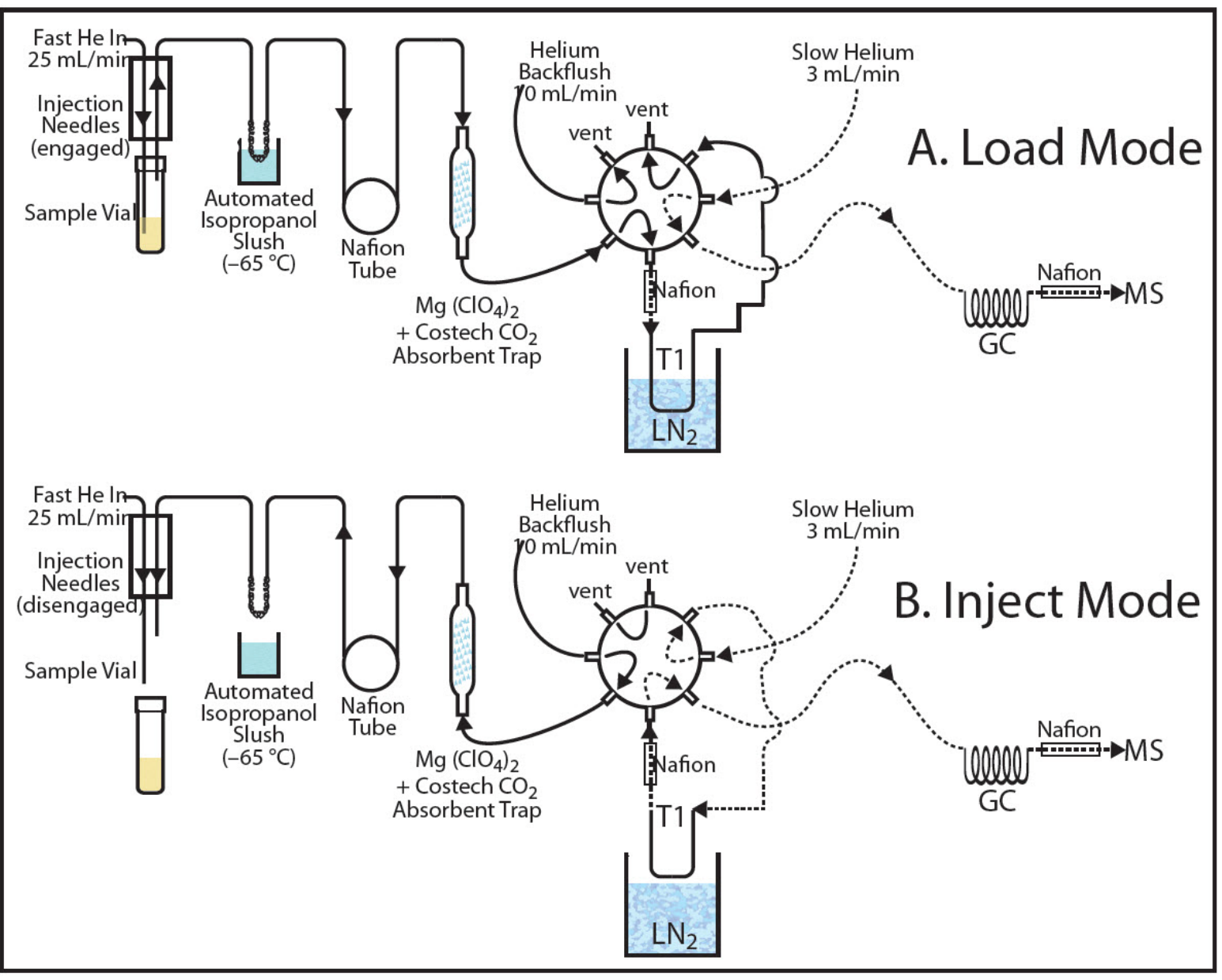

Figure 1. Schematic of modified Finnigan MAT (now Thermo Scientific) GasBench 2 inlet system. 
The automated sample extraction and analysis unit is constructed to hold 32 samples and is furnished with a CTC Analytical CombiPAL robotic sampling arm by which the sample ultimately is sent to the IRMS through a volatile organic vapor and water removal unit (an automated $-65{ }^{\circ} \mathrm{C}$ isopropanol-slush trap), a water removal unit (Nafion drier), $\mathrm{CO}_{2}$ and water removal unit (Costech \#021020 carbon dioxide absorbent and $\mathrm{Mg}\left(\mathrm{ClO}_{4}\right)_{2}$ /Ascarite trap), a cryogenic trap, a GC column, another water removal unit (Nafion drier), and an open split. To eliminate the need for an automatic liquid-nitrogen-trap filler, the stroke of the trap of the Finnigan MAT GasBench 2 was increased from 25 centimeter $(\mathrm{cm})$ to $40 \mathrm{~cm}$ by replacing the SMC model C85KN20-250 piston with a model C85KN20-400 piston. The liquid nitrogen dewar of the Finnigan MAT GasBench 2 was replaced by one with an inner diameter of $9.5 \mathrm{~cm}$ and an inner depth of $49 \mathrm{~cm}$, which held liquid nitrogen for $20 \mathrm{~h}$. The CTC CombiPAL autosampler is fitted with a LEAP Technologies, Inc. headspace sampler (P/N PAL.VENTTOOL). Helium enters the sample vial through a 17-cm-long 22s-gauge side-hole inlet needle (Hamilton \#17305). Helium and sample gas exit the sample vial through a 22-gauge sidehole outlet needle. Bending of the inlet needle during septum penetration is minimized by using a 22s-gauge needle and by reducing the Z-axis motor speed of the CombiPAL to 500 millimeters per second $(\mathrm{mm} / \mathrm{s})$. The helium inlet needle is held by a VICI bulkheadreducing union (ZBRU1.5) mounted in a 1-mL CombiPAL syringe holder. The lower needle guide of the CombiPAL was lowered $4 \mathrm{~cm}$ by adding a pair of 4 -cm stainless steel extenders. The Finnigan MAT sample holder was replaced with a 32-hole VT32-20 CombiPAL sample holder, which was screwed to the base of the CombiPAL. Because the friction of the needles in the vial septum is sufficiently high to pull vials with samples out of the sample holder, a 32-hole (2.222-cm diameter holes), 6.3-millimeter (mm)-thick aluminum plate was positioned over the vials and held down by screws extending from the sample holder. The CTC Analytical CombiPAL autosampler allows separate helium inflow (25 milliliters per minute $(\mathrm{mL} / \mathrm{min})$ ) to purge the entire vial and a helium $+\mathrm{N}_{2} \mathrm{O}$ outflow for sample collection. The purged sample flows through a Nafion water removal tube and is collected for 13 minutes (min) in the cryogenic trap (95 $\times 0.16 \mathrm{~cm}$-outside-diameter, stainless steel) submerged in liquid $\mathrm{N}_{2}\left(-192{ }^{\circ} \mathrm{C}\right)$. By removing the trap from liquid $\mathrm{N}_{2}$, the sample warms to room temperature, and the sublimed sample is released to the GC (PoraPLOT Q CP7551, held at room temperature) under a helium flow rate of $3 \mathrm{~mL} / \mathrm{min}$ through a Nafion drier, an open split that limits the flow to $0.3 \mathrm{~mL} / \mathrm{min}$, and ultimately into the IRMS. To ensure sufficient separation of $\mathrm{CO}_{2}$ and $\mathrm{N}_{2} \mathrm{O}$, the original 25-m PoraPLOT Q CP7551 GC column has been extended to $37.5 \mathrm{~m}$.

The IRMS is a Thermo Scientific Delta V Plus CF-IRMS (fig. 2). The fundamental principle of the CF-IRMS technique is that a carrier gas transports the analyte through an initial stage of online chemistry for conversion to a form acceptable by the IRMS (Brenna and others, 1997), in this case $\mathrm{N}_{2} \mathrm{O}$ gas. This is an automated system generating online, high-precision $\delta$ values. In the IRMS, gas molecules are ionized in a source by electrons emitted from a hot filament. The ions are accelerated into an analyzer, forming an ion beam, are separated in a magnetic field, and then collected in Faraday-cup collectors. The ion-beam intensities are measured with electrometers. This IRMS has a universal triple collector, consisting of two

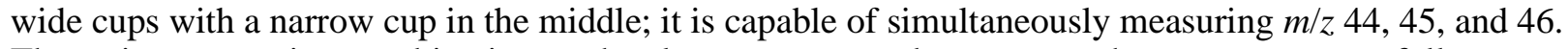
The resistor-capacitor combination on the electrometers used to measure these masses are as follows: $3 \times 10^{8}$ ohms $(\Omega)$ and 680 picofarads (pF) for cup $1,3 \times 10^{10} \Omega$ and $5 \mathrm{pF}$ for cup 2 , and $3 \times 10^{11} \Omega$ and $2 \mathrm{pF}$ for cup 3.

The Finnigan ISODAT 2.0 software (1) controls the Finnigan MAT GasBench 2 preparation system, (2) operates the IRMS, (3) acquires data from the IRMS, and (4) calculates delta values. 


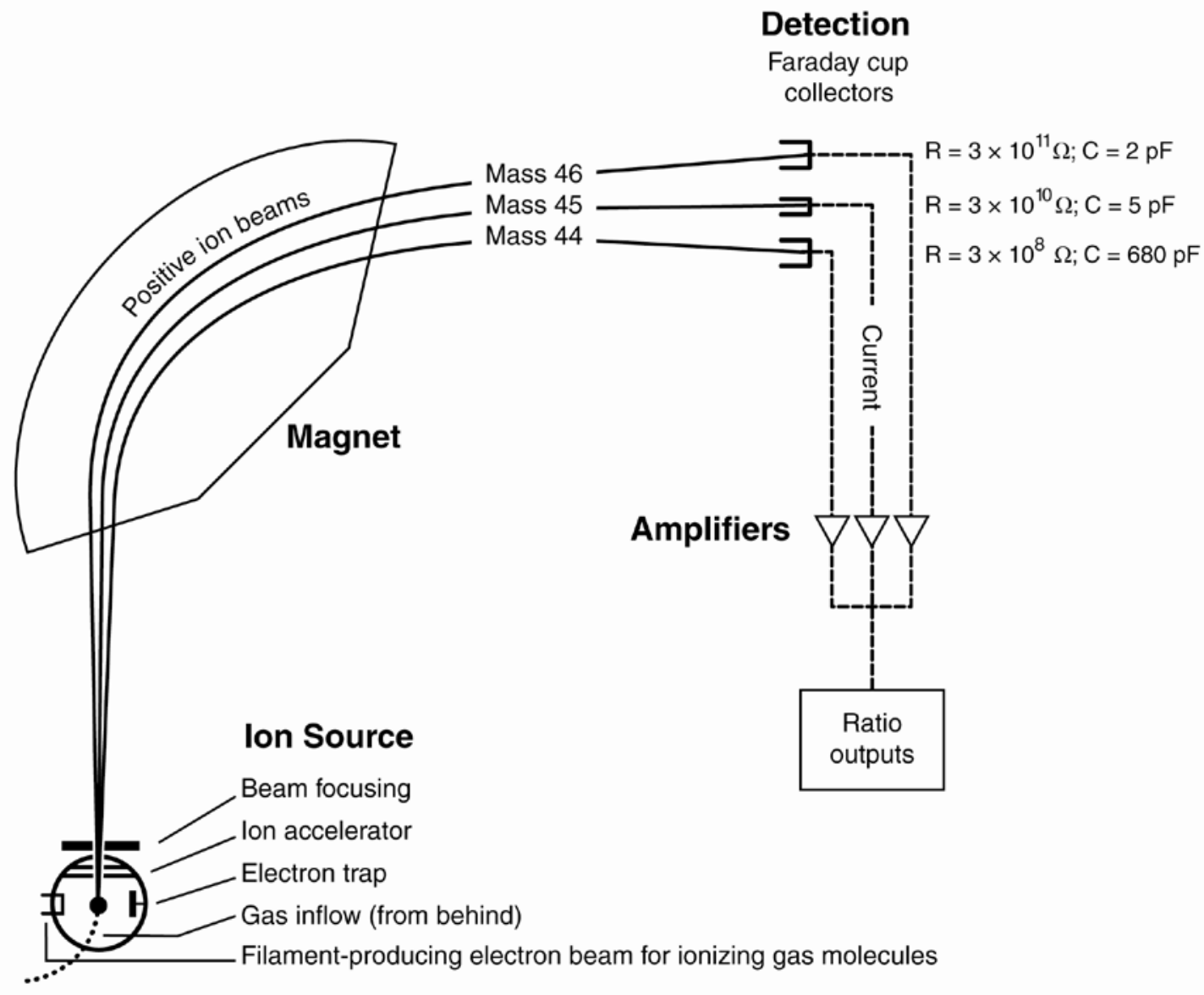

Figure 2. Schematic of a continuous flow isotope-ratio mass spectrometer (CF-IRMS) (modified from Clark and Fritz, 1997).

\section{Sample Collection, Preparation, Analysis, Retention Times, and Disposal}

\section{Sample Containers, Preservation, and Handling Requirements}

Each sample is collected in a high-density polyethylene (HDPE) scintillation vial with a Polyseal cap (Wheaton 986706), available from the RSIL. Sample size should be approximately $30 \mathrm{~g}$, with a nitrogen concentration more than $0.03 \mathrm{mg} / \mathrm{kg}$ as nitrogen, and should be dried to prevent any biological conversion of nitrogen-bearing material to $\mathrm{NO}_{3}^{-}$during storage or transportation. The bottles are labeled with isotopes, whose concentrations are determined along with the respective laboratory code or schedule number. No treatment, preservation, or special shipping is required. 


\section{Sample Preparation and Time Requirements}

Sample preparation involves logging in samples to the LIMS-LSI (see appendix A). The logging-in procedure involves logging samples in batches to LIMS-LSI that could contain from 1 to 100 samples per batch (also called a project), printing labels for each sample, and printing a summary project report. Each sample label contains the Field ID (the identifier by which the sample submitter knows each sample) and the unique RSIL Lab ID assigned by the LIMS-LSI. The summary project report is inserted into a threering binder titled "Samples in Progress."

A sample work-order sheet is created by LIMS-LSI by printing a "Template" and a "Samples-to-Be Analyzed” form; step-by-step procedures are given in appendix B. The time requirement for this preparation is about 1 to 5 days.

\section{Performing the Analysis and Time Requirements}

Approximately 30 milligrams (mg) of solid sample is placed in a 150-mL beaker and $80 \mathrm{~mL}$ of deionized water (DIW) is added; this mixture needs to be stirred well and allowed to sit covered overnight. The sample is then filtered with 0.2 -micron filter and rinsed several times with 10 -mL aliquots of DIW, not to exceed more than $300 \mathrm{~mL}$ of water in total. An aliquot is removed for determination of $\mathrm{NO}_{3}{ }^{-}$concentration, and the remainder is preserved with one pellet of sodium hydroxide.

A denitrifier culture is prepared by cultivating the appropriate strain of Pseudomonas aureofaciens for $\delta^{15} \mathrm{~N}$ determination. Using tryptic soy broth (TSB) medium amended with $10-\mathrm{mM} \mathrm{NO}_{3}^{-}$and $15-\mathrm{mM}$ $\mathrm{NH}_{4}{ }^{+}$, the bacteria are first inoculated in a starter tube that contains $5 \mathrm{~mL}$ of culture medium. The bacteria are allowed to grow overnight, and then transferred into autoclaved 580-mL serum bottles containing $500 \mathrm{~mL}$ of medium.

The bacteria (5- to 10-day-old cultures) are harvested by centrifugation in four 200-mL centrifuge bottles and resuspended with a total of $100 \mathrm{~mL}$ of new medium that contains no $\mathrm{NO}_{3}^{-}$to achieve a 5-fold increase in concentration. Several drops of antifoaming agent are added to the 100 -mL concentrated cells. The 3-mL concentrated cells are dispensed into thirty-two 20-mL headspace vials. The vials are sealed with a Teflon-aluminum-lined silicone septum and purged with helium for $1 \mathrm{~h}$. At this point, the TSB in the vials should be $\mathrm{NO}_{3}^{-}$and nitrite $\left(\mathrm{NO}_{2}^{-}\right)$free, and the headspace helium should be $\mathrm{N}_{2} \mathrm{O}$ free.

An amount between 1 and $10 \mathrm{~mL}$ of a sample containing dissolved $\mathrm{NO}_{3}^{-}$is added to the prepared vials to achieve a constant amount of analyte $\mathrm{N}_{2} \mathrm{O}$, typically 10 to 20 nanomoles (nmol). For this reason, the sample submitter must provide the $\mathrm{NO}_{3}^{-}$concentrations of each sample. After the samples are injected, the sample vials are stored upside down for at least $2 \mathrm{~h}$ to minimize leakage through the septum while $\mathrm{NO}_{3}^{-}$is converted to $\mathrm{N}_{2} \mathrm{O}$. The step-by-step procedure is given in appendix C.

After a 2-h conversion, the 32 vials that typically have 20 unknown samples and 12 references, among which are 4 vials of N-7 (USGS32; $\mathrm{KNO}_{3}$ ), 4 vials of N-34 (USGS34; $\mathrm{KNO}_{3}$ ), and 4 vials of N-35 (USGS35), are analyzed. N-7 and N-34 are used to calibrate $\delta^{15} \mathrm{~N}$ values. The sample vials are loaded into a 32-position aluminum tray that is accessed by the autosampler. The process is automated and controlled by the ISODAT 2.0 mass spectrometer program; therefore, it requires entering sample identifications into the "Sequence Table" in ISODAT 2.0, choosing appropriate "Methods" (the method that controls the CTC Analytical CombiPAL system and the method that controls the analysis, both of which were set up previously in the system), and starting sequence acquisition. The step-by-step procedure is given in appendix D.

For each sample analysis, the vial is purged by the autosampler for 13 min using helium gas at a flow rate of $30 \mathrm{~mL} / \mathrm{min}$. The flow from the exit needle is directed through a $-65{ }^{\circ} \mathrm{C}$ isopropanol-slush trap, a Nafion drier, followed by $\mathrm{Mg}\left(\mathrm{ClO}_{4}\right)_{2}$ and Costech \#021020 carbon dioxide absorbent to remove volatile organic vapor, water, and $\mathrm{CO}_{2}$ from the gas stream before trapping $\mathrm{N}_{2} \mathrm{O}$ under liquid nitrogen. The $\mathrm{N}_{2} \mathrm{O}$ is then released from the liquid nitrogen trap and is passed through a PoraPLOT Q CP7551 GC column and on to the IRMS. 
After the analyses are completed, the data are exported from the ISODAT 2.0 database to a removable disc or "memory stick" (see appendix E) and imported to LIMS-LSI, and transferred to a Data Back-Up Computer. Final daily correction factors are determined (see appendix F) based on the daily analyses of reference materials using equations 4 and 5, which are represented with numerical values:

$$
\begin{aligned}
& +180 \%=m \times \delta^{15} \mathrm{~N}_{\mathrm{USGS}_{2} / \text { workingrefgas }}+b \\
& -1.8 \%=m \times \delta^{15} \mathrm{~N}_{\mathrm{USGS} 34 / \text { workingrefgas }}+b
\end{aligned}
$$

The values $+180 \%$ and $-1.8 \%$ are the assigned values of the two international reference materials USGS32 and USGS34, respectively. The $\delta^{15} \mathrm{~N}$ values in equations 4 and 5 are the mean daily delta values of the respective international reference materials relative to the working reference gas, $b$ is the additive correction factor, and $m$ is the expansion coefficient correction factor. When two or more reference materials with different isotopic compositions are analyzed, the correction for sample blank does not need to be applied if the magnitude of the blank in the samples and reference materials is identical. However, if only a single reference material is analyzed, only one point calibration is possible; in that case, a blank correction must be applied.

If replicates do not agree within acceptable tolerances, they are analyzed until acceptable statistics are achieved. The computerized LIMS-LSI will not release data until the statistics are acceptable. The time requirement for performing the analyses described earlier is a minimum of 2 days if the bacterial culture is already prepared.

The systematic procedure is listed in the "Lab Procedures" binder. The supervisor should review suggested changes before they are adopted.

\section{Problematic Samples}

Problematic samples include (1) samples that have concentrations less than $14 \mu \mathrm{g}$ of nitrogen per liter, (2) samples that have a mixture of $\mathrm{NO}_{3}^{-}$and $\mathrm{NO}_{2}^{-}$, because this technique does not distinguish between these two forms of nitrogen, and (3) samples that have been poisoned with mercury chloride or other preservatives. Samples that have anomalous $n\left({ }^{17} \mathrm{O}\right) / n\left({ }^{16} \mathrm{O}\right)$ ratios can be problematic for $\delta^{15} \mathrm{~N}$ analysis because the $\delta^{15} \mathrm{~N}$ calculation assumes that the fractionation of oxygen isotopes in the $\mathrm{NO}_{3}^{-}$is mass dependent, that is, that $\delta^{17} \mathrm{O}=0.52 \times \delta^{18} \mathrm{O}$. For samples containing atmospheric $\mathrm{NO}_{3}^{-}$that have excess ${ }^{17} \mathrm{O}$, the bacterial method may overestimate the $\delta^{15} \mathrm{~N}$ values by as much as 1 to $2 \%$. Therefore, for samples that are expected to contain more than 20-percent atmospheric $\mathrm{NO}_{3}^{-}$, users should contact the RSIL for methods to quantify $\delta^{17} \mathrm{O}$ values and determine accurate $\delta^{15} \mathrm{~N}$ values.

\section{Interferences}

Because $\mathrm{CO}_{2}$ has the same $\mathrm{m} / \mathrm{z}$ values as $\mathrm{N}_{2} \mathrm{O}$, it poses an analytical interference if it is not completely removed from the sample stream. Ammonia $\left(\mathrm{NH}_{4}{ }^{+}\right)$and dissolved organic nitrogen do not cause interference. To ensure a sufficient separation of $\mathrm{CO}_{2}$ from $\mathrm{N}_{2} \mathrm{O}$, the original 25-m PoraPLOT Q CP7551 GC column has been extended to $37.5 \mathrm{~m}$ in length.

When analyzing $\mathrm{KOH}$ - or $\mathrm{NaOH}$-preserved samples with a typical $\mathrm{pH}$ of about 11, if weaker or older bacteria are used, the $\mathrm{N}_{2} \mathrm{O}$ yield and isotopic results can be affected because very basic sample solutions can kill the denitrifier bacteria, especially for samples containing very small amounts of nitrate. In such a case, several milliliters of raw sample are needed. 


\section{Troubleshooting and Bench Notes}

Bacterial growth during the initial culture phase is monitored by the amount of $\mathrm{NO}_{3}^{-}$remaining in the medium solution. In a healthy culture, $\mathrm{NO}_{2}^{-}$is completely consumed in 5 to 7 days. If $\mathrm{NO}_{3}^{-}$is not completely consumed in 7 days, the culture is discarded.

\section{Maintenance and Maintenance Records}

Stocks of bacteria are in a $-80{ }^{\circ} \mathrm{C}$ freezer. New plates are streaked from that stock and transferred on agar plates. After 3 to 5 days, the second plates are streaked by individual colonies from the first plates. Likewise, the third-generation plates can be streaked from the second plates. The working cultures are inoculated only from the second and third-generation plates. The history of all working cultures is kept in a culture log, with the bacterial strain, date of inoculation, source of inoculum, and date of harvest.

The isopropanol-slush trap is replaced every few weeks. The Nafion driers require replacement every 8 to 10 months. The $\mathrm{Mg}\left(\mathrm{ClO}_{4}\right)_{2}$ and Costech \#021020 carbon dioxide absorbent is repacked every 1 to 2 months. The GC is baked out $\left(150^{\circ} \mathrm{C}\right.$ overnight $)$ as needed.

The IRMS requires a daily check (see appendix G). A logbook is kept for each IRMS, where notes of maintenance checks, normal settings, problems, and repairs are listed.

Routine maintenance is necessary for the upkeep of the IRMS vacuum system, including (1) checking the pump performance from time to time, (2) changing the pump oil, and (3) changing the oil cartridge in each turbomolecular pump at 6-month intervals. Pump conditions are listed, such as date of oil changes, problems, and repairs in the pump database (file path C:IRSILlvacuum pumps).

Maintenance of ISODAT 2.0 includes importing/transferring results from the ISODAT 2.0 database to the LIMS-LSI computer hard disk and the Data Back-Up computer hard disk (appendix E).

\section{Sample Retention Time and Disposal}

Samples are retained in the RSIL for at least 4 months after reporting data. Samples are then discarded unless the submitter has requested that the samples be returned.

The ISODAT sample files from the IRMS computer are kept indefinitely on two different hard disks of the Data Back-Up computer. Paper reports are kept for a few weeks. Analytical results from the IRMS are exported to LIMS-LSI and kept indefinitely. No data are entered by hand, and no manual calculations are performed on the data.

\section{Data Acquisition, Processing, Evaluation, Quality Control, and Quality Assurance}

\section{Laboratory Information Management System for Light Stable Isotope (LIMS-LSI)}

In the RSIL, the LIMS-LSI (Coplen, 2000) is used for data processing and evaluation. This system is a database program capable of (1) storing information about samples, (2) storing the results of mass spectrometric delta values of samples after importing from the ISODAT database, (3) calculating analytical results using standardized algorithms stored in a database, (4) normalizing delta values using isotopic reference materials, and (5) generating templates to facilitate loading of samples. With this system, the following are ensured: (1) quality assurance (QA), (2) laboratory efficiency, (3) reduction of workload and errors owing to the elimination of retyping of data by laboratory personnel, and (4) a decrease of errors in data reported to sample submitters. This database provides a complete record of 
information on how laboratory reference materials have been analyzed and provides a record of what correction factors have been used as an audit trail for the RSIL.

\section{Quality Control (OC) Samples}

Samples are prepared and analyzed in batches-a maximum of 32 daily. Each batch contains approximately 12 vials of 3 reference materials; one pair depleted in ${ }^{15} \mathrm{~N}$ and ${ }^{18} \mathrm{O}$ and another pair enriched in ${ }^{15} \mathrm{~N}$ and ${ }^{18} \mathrm{O}$. All of these reference materials serve as QC samples. Daily, the analyst (1) examines the computer printouts for indications of analytical problems, (2) determines the daily additive and expansion correction factors by the LIMS-LSI, and (3) applies correction factors to isotopic data. The values of these correction factors along with the date and range of analysis numbers are recorded manually in the laboratory "GasBench Book," even though the data are already in the LIMS-LSI. After printing the list of isotopic results from the "Table of Samples in Progress," the analyst reviews the results, determines which samples need to be analyzed a third time to achieve acceptable results (i.e., $\Delta \delta \leq 0.25 \%$ o for $\delta^{15} \mathrm{~N}$ ) and puts them back to the template. The final average isotopic values for each QC sample, with dates and analysis numbers, are recorded manually in the laboratory "GasBench book" even though the data are already in LIMS-LSI.

\section{Acceptance Criteria for All OC Samples}

Acceptance criteria for QC samples are the same as acceptance criteria for the samples. The rules are as follows:

- If standard deviation is less than or equal to $0.25 \%$ for $\delta^{15} \mathrm{~N}$, use mean delta.

- If there are three or more analyses, delete the outlier and recalculate.

- If standard deviation of this recalculation is less than or equal to $0.25 \%$ o for $\delta^{15} \mathrm{~N}$, use the mean from this recalculation.

- If none of these is the case, the result is not acceptable, and corrective action is required.

The RSIL estimates the expanded uncertainty $\left(U=2 \mu_{\mathrm{c}}\right)$ of $\delta^{15} \mathrm{~N}$ measurement results. The expanded uncertainty provides an envelope that represents a 95-percent probability of encompassing the true value that has been determined from the aggregation of measurement results over a period of time. The expanded uncertainty can be determined using the guide to the expression of uncertainty (Joint Committee for Guides in Metrology, Working Group 1 (JCGM/WG1), 2010). The application of expanded uncertainty to the reporting of stable isotope measurements is discussed by Coplen and others (2006). The estimated expanded uncertainty of $\delta^{15} \mathrm{~N}$ measurement results for samples with nitrate concentrations of at least $0.06 \mathrm{mg} / \mathrm{kg}$ as nitrogen is $\pm 0.5 \%$ unless otherwise specified, and this value is conservative. If any given sample were resubmitted to the RSIL for nitrogen isotopic analysis, the measured value would fall within the uncertainty bounds of the previous result more than 95 percent of the time. The $\delta^{15} \mathrm{~N}$ uncertainty for nitrate samples with concentrations less than $0.06 \mathrm{mg} / \mathrm{kg}$ as nitrogen is $\pm 1.0 \%$ unless otherwise specified.

\section{Corrective Action Requirements}

If an analyst finds any problem with the daily reference-sample data, the analyst contacts the supervisor. The trouble-shooting process will require an evaluation and reanalysis of certain samples to identify the origin of the problem.

If samples do not give satisfactory results after three or more separate analyses, the analyst averages all the data and reports the mean value. Such analytical results are indicated with a comment, and the 
customer will be advised by e-mail or other means. If the sample was submitted through the NWQL, it is the responsibility of the customer to determine whether the data need to be qualified.

\section{Responsible Parties for All QC/QA Functions for Procedures Covered in RSIL SOPs}

The analyst, with supervisor approval, is responsible for qualifying data and notifying customers.

\section{Data Management and Records}

In addition to evaluating daily sample analyses, every week, an analyst evaluates the data project-byproject, reports results to the customers, and files final project data reports in the laboratory

“Correspondence” binder (appendix H).

\section{Health, Safety, and Waste-Disposal Information}

\section{Applicable Health and (or) Safety Issues}

\section{Personal Protection}

Safety glasses and protective gloves are recommended whenever samples are handled, especially when the samples are of biological origin. For other precautions and safety procedures, consult the Material Safety Data Sheets (MSDS); they are on file in the laboratory and at the URL http://www.ilpi.com/msds/\#Manufacturers. This URL provides links to the MSDSs of most chemical companies.

\section{Electrical Hazards}

Electrical systems must conform to the National Electric Code, National Fire Protection Association Code (NFPA 70-1971), and the American National Standards Institute (ANSI) Code (C1-1971). For more information, consult the U.S. Geological Survey's Safety and Environmental Health Handbook (U.S. Geological Survey, 2002, sec. 4-4.1).

Shock hazards exist inside the instruments. Only an authorized service representative or an individual with training in electronic repair must remove panels or circuit boards where voltages are greater than 20 volts. The instruments require a third-wire protective grounding conductor. Three-to-two wire adapters are unsafe for these instruments.

\section{Chemical Hazards}

Use protective gloves to handle all chemicals.

\section{Gas Cylinder Handling}

Compressed gas cylinders must be handled and stored according to the U.S. Geological Survey's Safety and Environmental Health Handbook (U.S. Geological Survey, 2002, sec. 4-4.5.1). Each cylinder must be (1) carefully inspected when received; (2) securely fastened at all times with an approved chain assembly or belt; (3) capped at all times when not in use; (4) capped when transported; (5) transported 
only by a properly designed vehicle (hand truck); and (6) stored separately with other full, empty, flammable, or oxidizing tanks of gas, as appropriate.

\section{Biological Hazard}

The bacteria used in this method are not a significant health hazard. However, infection may occur if bacterial culture comes in contact with open wounds or if needles that have been used with the bacteria puncture the skin. If contact with bacterial culture occurs, wash the affected area thoroughly with water and use an alcohol swab (70-percent EtOH) to cleanse the affected area.

The used or old bacterial cultures should be killed by autoclaving at $120{ }^{\circ} \mathrm{C}$ for 30 min before sink disposal.

Needles that have been used with the bacteria should be placed in a "Sharps" container, sealed, and disposed of when the container is full. The container should be labeled "biological hazard" and disposed of in the same manner in which hazardous chemicals are disposed.

\section{Specific Waste-Disposal Requirements}

The used or old bacterial culture should be killed by autoclaving at $120{ }^{\circ} \mathrm{C}$ for 30 min before disposal in the sink. 


\section{Revision History}

Publication Series and Series Number: Techniques and Methods 10-C12 (Book 10, Section C, Chapter 12)

Publication Title: Determination of the $\delta^{15} \mathrm{~N}$ of Nitrate in Solids; RSIL Lab Code 2894

Publication Authorship: Coplen, Tyler B., Qi, Haiping, Révész, Kinga, Casciotti, Karen, and Hannon, Janet E.

Version 1.0, 2007

Version 1.1, 2012

Summary of Revised Product Components

\begin{tabular}{|c|c|c|c|}
\hline Component & Description & $\begin{array}{c}\text { Last Revised } \\
\text { In Publication Version }\end{array}$ & $\begin{array}{c}\text { Date of } \\
\text { Last Revision }\end{array}$ \\
\hline Title & $\begin{array}{l}\text { Replaced } \delta\left({ }^{15} \mathrm{~N} / /^{14} \mathrm{~N}\right) \text { by } \delta^{15} \mathrm{~N} \text { to be in } \\
\text { accordance with recommendations of the } \\
\text { Commission on Isotopic Abundances and } \\
\text { Atomic Weights of the International Union } \\
\text { of Pure and Applied Chemistry. }\end{array}$ & 1.1 & July 2012 \\
\hline Authorship & $\begin{array}{l}\text { Tyler B. Coplen, Haiping Qi, and Janet E. } \\
\text { Hannon added as coauthors. }\end{array}$ & 1.1 & July 2012 \\
\hline $\begin{array}{l}\text { Summary of } \\
\text { procedure }\end{array}$ & Updated text to reflect new instrumentation. & 1.1 & July 2012 \\
\hline $\begin{array}{l}\text { Reporting units } \\
\text { and operational } \\
\text { range }\end{array}$ & $\begin{array}{l}\text { Updated text to reflect expression of delta } \\
\text { values with number ratios. }\end{array}$ & 1.1 & July 2012 \\
\hline $\begin{array}{l}\text { Reference } \\
\text { materials and } \\
\text { documentation }\end{array}$ & $\begin{array}{l}\text { Updated text to reflect improved method of } \\
\text { Coplen and others (2004). }\end{array}$ & 1.1 & July 2012 \\
\hline $\begin{array}{l}\text { Labware, } \\
\text { instrumentation, } \\
\text { and reagents }\end{array}$ & Update text to reflect new instrumentation. & 1.1 & July 2012 \\
\hline $\begin{array}{l}\text { Sample } \\
\text { collection, } \\
\text { preparation, } \\
\text { analysis, } \\
\text { retention times, } \\
\text { and disposal }\end{array}$ & $\begin{array}{l}\text { Updated text to reflect that samples are no } \\
\text { longer submitted through the National } \\
\text { Water Quality Laboratory (NWQL) and } \\
\text { improved analytical techniques. }\end{array}$ & 1.1 & July 2012 \\
\hline
\end{tabular}




\begin{tabular}{|c|c|c|c|}
\hline $\begin{array}{l}\text { Data acquisition, } \\
\text { processing, } \\
\text { evaluation, } \\
\text { quality control, } \\
\text { and quality } \\
\text { assurance }\end{array}$ & $\begin{array}{l}\text { Updated text to reflect that samples are no } \\
\text { longer submitted through the National } \\
\text { Water Quality Laboratory (NWQL). }\end{array}$ & 1.1 & July 2012 \\
\hline $\begin{array}{l}\text { Health, safety, } \\
\text { and waste- } \\
\text { disposal } \\
\text { information }\end{array}$ & $\begin{array}{l}\text { Updated text to reflect improved method of } \\
\text { Coplen and others (2004). }\end{array}$ & 1.1 & July 2012 \\
\hline References cited & Added four references. & 1.1 & July 2012 \\
\hline Appendix A & $\begin{array}{l}\text { Updated text to reflect that samples are no } \\
\text { longer submitted through the National } \\
\text { Water Quality Laboratory (NWQL). }\end{array}$ & 1.1 & July 2012 \\
\hline Appendix B & $\begin{array}{l}\text { Updated text to reflect improved method of } \\
\text { Coplen and others (2004). }\end{array}$ & 1.1 & July 2012 \\
\hline Appendix C & $\begin{array}{l}\text { Updated text to reflect improved method of } \\
\text { Coplen and others (2004). }\end{array}$ & 1.1 & July 2012 \\
\hline Appendix H & $\begin{array}{l}\text { Updated text to reflect that samples are no } \\
\text { longer submitted through the National } \\
\text { Water Quality Laboratory (NWQL). }\end{array}$ & 1.1 & July 2012 \\
\hline Main text footer & Removed from document. & 1.1 & July 2012 \\
\hline
\end{tabular}




\section{References Cited}

Böhlke, J.K., Gwinn, C.J., and Coplen, T.B., 1993, New reference materials for nitrogen-isotope-ratio measurements: Geostandards Newsletter, v. 17, p. 159-164.

Böhlke, J.K., and Coplen, T.B., 1995, Interlaboratory comparison of reference materials for nitrogenisotope-ratio measurements, in Reference and Intercomparison Materials for Stable Isotopes of Light Elements: Vienna, Austria, International Atomic Energy Agency, IAEA-TECDOC-825, p. 51-66.

Böhlke, J.K., Mroczkowski, S.J., and Coplen, T.B., 2003, Oxygen isotopes in nitrate: New reference materials for ${ }^{18} \mathrm{O}:{ }^{17} \mathrm{O}:{ }^{16} \mathrm{O}$ measurements and observations on nitrate-water equilibration: Rapid Communications in Mass Spectrometry, v. 17, p. 1835-1846.

Brenna, J.T., Corso, T.N., Tobias, H.J., and Caimi, R.J., 1997, High-precision continuous-flow isotoperatio mass spectrometry: Mass Spectrometry Reviews, v. 16, p. 227-258.

Casciotti, K.L., Sigman, D.M., Hastings, M., Böhlke, J.K., and Hilkert, Andreas, 2002, Measurement of the oxygen isotopic composition of nitrate in seawater and freshwater using the denitrifier method: Analytical Chemistry, v. 74, p. 4905-4912.

Clark, Ian, and Fritz, Peter, 1997, Environmental isotopes in hydrogeology: Boca Raton, Fla., Lewis Publishers, 328 p.

Coplen, T.B., 2000, A guide for the laboratory information management system (LIMS) for light stable isotopes-Version 7 and 8: U.S. Geological Survey Open-File Report 00-345, 121 p., accessed April 27, 2012, at http://water.usgs.gov/software/code/geochemical/lims/doc/ofr00345.pdf.

Coplen, T.B., 2011, Guidelines and recommended terms for expression of stable-isotope-ratio and gasratio measurement results: Rapid Communications in Mass Spectrometry, v. 25, p. 2538-2560, accessed April 27, 2012, at http://onlinelibrary.wiley.com/doi/10.1002/rcm.5129/abstract.

Coplen, T.B., Böhlke, J.K., and Casciotti, K.L., 2004, Using dual-bacterial denitrification to improve $\delta^{15} \mathrm{~N}$ determinations of nitrates containing mass-independent ${ }^{17} \mathrm{O}$ : Rapid Communications in Mass Spectrometry, v. 18, p. 245-250.

Coplen, T.B., Brand, W.A., Gehre, Matthias, Gröning, Manfred, Meijer, H.A.J., Toman, Blaza, and Verkouteren, R.M., 2006, New guidelines for $\delta^{13} \mathrm{C}$ measurements: Analytical Chemistry, v. 78, no. 7, p. 2439-2441.

Joint Committee for Guides in Metrology, Working Group 1 (JCGM/WG1), 2010, Evaluation of measurement data-Guide to the expression of uncertainty in measurement (known as the GUM) (2010 corrected version of the first edition of 2008): Joint Committee for Guides in Metrology [publication] JCGM 100:2008, 120 p., accessed July 16, 2012, at http://www.bipm.org/en/publications/guides/.

Mariotti, A., 1983, Atmospheric nitrogen is a reliable standard for natural ${ }^{15} \mathrm{~N}$ abundance measurements: Nature, v. 303, p. 685-687.

Révész, Kinga, Qi, Haiping, and Coplen, T.B., 2012, Determination of the $\delta^{15} \mathrm{~N}$ of total nitrogen in solids; RSIL lab code 2893, chap. 11 of Stable isotope-ratio methods, sec. C of Révész, Kinga, and Coplen, T.B. eds., Methods of the Reston Stable Isotope Laboratory (slightly revised from version 1.1 released in 2007): U.S. Geological Survey Techniques and Methods, book 10, 31 p., available only online at http://pubs.usgs.gov/tm/2006/tm10c11/. (Supersedes versions 1.0 and 1.1 released in 2006 and 2007, respectively.)

Sigman, D.M., Casciotti, K. L., Andreani, M., Barford, C., Galanter, M., and Böhlke, J.K., 2001, A bacterial method for the nitrogen isotopic analysis of nitrate in seawater and freshwater: Analytical Chemistry, v. 73, p. 4145-4153.

U.S. Geological Survey, 2002, USGS handbook 445-3-H, Safety and environmental health handbook, $435 \mathrm{p}$. 


\section{Appendix A. Step-by-Step Procedure to Log-In Samples to LIMS-LSI}

1. For sample submitter:

a. Download "Standard Submission Excel Form” or the "QWDATA Compatible Submission Excel Form” from the RSIL Web site at http://isotopes.usgs.gov/.

b. Fill out the requested sample information.

c. Send a diskette or CD and a hard copy along with the samples or e-mail the completed RSIL Excel worksheet to isotopes@usgs.gov.

2. For RSIL personnel:

a. Match up information on sample bottles with the submitted "Standard Submission Excel Form" or the "QWDATA Compatible Submission Excel Form."

b. Enter all Standard Submission Excel Form or "QWDATA Compatible Submission Excel Form” information into LIMS-LSI by loading media. Submission date is the date samples are logged in.

c. Use "Import a New Project From Excel Submission” in LIMS-LSI to assign G\#s.

d. Print out one project report and container labels (one for each sample).

e. Put a label on each sample bottle and cross-check Field IDs between bottles and Excel worksheet forms.

f. Punch holes in the original Excel worksheet and all the project information you have and put in "Samples-in-Progress" binder. 


\section{Appendix B. Step-by-Step Procedure to Print a Template and a Samples- to-Be-Analyzed List}

\section{Template}

1. Use “Create a Sample List -->” in LIMS-LSI (fig. B-1).

2. Select appropriate template and mass spectrometer for GasBench, aureofaciens, and N\&O.

3. Design analysis sequence with 32 ports.

4. Click "Create Sample List for Mass Spec."

5. Add any sample information you want in column "Sample/Extraction Info."

6. Click "Save and Print."

7. Insert diskette to receive sample headings.

8. Click "OK."

9. Exit LIMS-LSI.

10. Write sample amount $(\mathrm{mL})$ needed to be loaded into each vial and write the date that samples should be analyzed on the paper template.

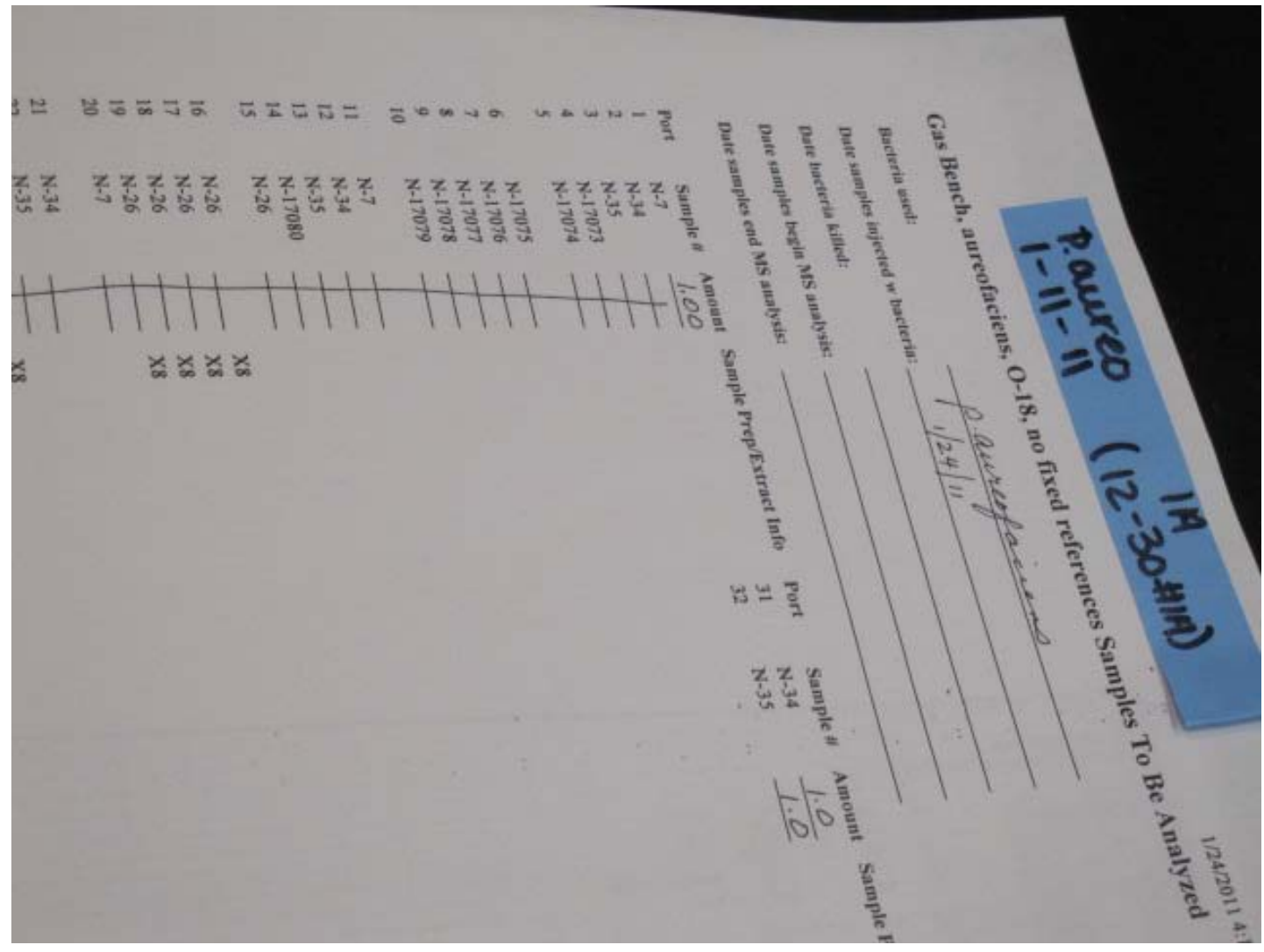

Figure B-1. Sample list generated by LIMS. 
Example of Samples-to-Be-Analyzed List 10/20/2003 3:54:33 PM

[N-7, N-34 and N-35 are reference materials]

\begin{tabular}{|l|l|l|}
\hline \multicolumn{1}{|c|}{ Port } & \multicolumn{1}{|c|}{ Sample \# } & Amount \\
\hline $\mathbf{1}$ & $\mathbf{N}-\mathbf{7}$ & \\
\hline $\mathbf{2}$ & N-34 & \\
\hline 3 & G-70 & \\
\hline 4 & G-71 & \\
\hline 5 & G-72 & \\
\hline & & \\
\hline 6 & G-73 & \\
\hline 7 & G-74 & \\
\hline 8 & G-75 & \\
\hline $\mathbf{9}$ & $\mathbf{N}-\mathbf{3 4}$ & \\
\hline $\mathbf{1 0}$ & $\mathbf{N}-\mathbf{7}$ & \\
\hline & & \\
\hline 11 & G-76 & \\
\hline 12 & G-77 & \\
\hline 13 & G-78 & \\
\hline 14 & G-79 & \\
\hline 15 & G-80 & \\
\hline & & \\
\hline 16 & G-81 & \\
\hline 17 & G-82 & \\
\hline 18 & G-83 & \\
\hline 19 & G-84 & \\
\hline $\mathbf{2 0}$ & $\mathbf{N}-\mathbf{3 4}$ & \\
\hline & & \\
\hline 21 & G-85 & \\
\hline 22 & G-86 & \\
\hline 23 & G-87 & \\
\hline 24 & G-88 & \\
\hline 25 & G-89 & \\
\hline & & \\
\hline 26 & G-90 & \\
\hline 27 & G-91 & \\
\hline 28 & G-92 & \\
\hline 29 & G-93 & \\
\hline 30 & G-94 & \\
\hline $\mathbf{3 1}$ & & \\
\hline $\mathbf{3 2}$ & $\mathbf{N}$ & \\
\hline
\end{tabular}




\section{Appendix C. Step-by-Step Preparation Procedure for Nitrogen Isotopic Analysis of Nitrate by Bacterial Denitrification}

\section{Making the Plates}

1. Preparing the plates:
a. Mix together:
i. 23 grams (g) of tryptic soy agar (TSA).
ii. $0.5 \mathrm{~g}$ of $\mathrm{KNO}_{3}$.
iii. $500 \mathrm{~mL}$ of E-pure or Milli-Q water.
b. Autoclave for $30 \mathrm{~min}$ at $120{ }^{\circ} \mathrm{C}$.
c. Cool 15 min (until you can handle the flask with a gloved hand).
d. Pour into sterile plastic Petri dishes, flaming the lip of the flask every 3 to 4 plates ( $500 \mathrm{~mL}$ of solution should make $\sim 20$ plates).
e. Allow the plates to solidify overnight.
f. Place all plates in a plastic bag. Label the bag with a piece of tape; include type of plates (TSA, plus $\mathrm{NO}_{3}^{-}$), today's date, and initials of technician who made the plates.
g. Store plates in the refrigerator until use.

2. Streaking the bacteria:
a. Remove the small box that contains the small tube of frozen stocks of Pseudomonas aureofaciens American, Type Culture Collection (ATCC) 13985 from the $-80{ }^{\circ} \mathrm{C}$ freezer.
b. Take bacteria from the frozen stock: Do not wait for the vial to thaw-use a sterile toothpick to scrape a very small amount of bacterial slush from the tube. CLOSE the tube before doing anything else. The frozen stocks are our most important resource.
c. Lightly touch the surface of a plate with the toothpick to transfer the bacterial slush. It should form a small puddle.
d. Using a flamed loop, spread the puddle by streaking back and forth through it. Flame the loop. Proceed with streaking by crossing trails twice with tracks of the first streak. Flame the loop. Cross trails twice with the second streak and proceed. This plate will be numbered as \#1.
e. To streak new plates from earlier plates: Using a single colony from \#1plate, streak, flame, streak, flame, streak (as above from frozen stocks). This plate will be numbered as \#2.
f. Plate labeling:
i. Strain (Pseudomonas aureofaciens).
ii. Plate number.
iii. Today's date.
iv. Source information in parentheses ("freezer" or date of earlier plate).

g. Plates take 3 to 5 days to mature so one will typically go through a round each week.

h. Keep plate lineages together for ease of organization. Discard old plate lineages when a new \#2 plate has matured and is ready to be used for inoculating. If streaking \#3s also streak new \#1s on the same day.

\section{Preparing the Tryptic Soy Broth (TSB)}

1. Wash the $580-\mathrm{mL}$ medium bottles $(580-\mathrm{mL}$ bottle with vial neck $(23 \times 75.5-\mathrm{mm}$ diameter and height, 20-mL volume)):
a. Brush and wash inside with Liqui-Nox detergent.
b. Rinse with warm water and deionized water (DIW).
c. Bake in $200{ }^{\circ} \mathrm{C}$ oven overnight. 
2. Making the medium: (making $7000 \mathrm{~mL}$ of medium and distributing it into fourteen $580-\mathrm{mL}$ serum bottles):
a. Mix together (fig. C-1):
i. 210 g of DIFCO Tryptic soy broth (TSB).
ii. $7.0 \mathrm{~g}$ of $\mathrm{KNO}_{3}$.
iii. $3.5 \mathrm{~g}$ of $\left(\mathrm{NH}_{4}\right)_{2} \mathrm{SO}_{4}$.
iv. $34.3 \mathrm{~g}$ of potassium phosphate.
b. Add $7000 \mathrm{~mL}$ of DIW.
c. Transfer the well-homogenized, $500 \mathrm{~mL}$ of medium into a $580-\mathrm{mL}$ bottle by peristaltic pump.
d. Seal bottles with blue butyl stoppers and aluminum crimp-seals.
e. Autoclave for $60 \mathrm{~min}$; the time starts after the autoclave reached $120^{\circ} \mathrm{C}$ (figs. $\mathrm{C}-2$ and $\mathrm{C}-3$ ).

3. Making the $\mathrm{NO}_{3}^{-}$-free medium: (making $2000 \mathrm{~mL}$ of medium and transferring it into twenty 100 -mL serum bottles):
a. Mix together:
i. $30 \mathrm{~g}$ of Tryptic soy broth.
ii. $0.5 \mathrm{~g}$ of $\left(\mathrm{NH}_{4}\right)_{2} \mathrm{SO}_{4}$.
iii. $4.9 \mathrm{~g}$ of $\mathrm{KH}_{2} \mathrm{PO}_{4}$.
b. Add $2000 \mathrm{~mL}$ of DIW.
c. Transfer the well-homogenized, $100-\mathrm{mL}$ volume of $\mathrm{NO}_{3}^{-}$-free medium into 160 -mL serum bottles by peristaltic pump.
d. Autoclave for $60 \mathrm{~min}$; the time starts after the autoclave reaches $120^{\circ} \mathrm{C}$ (fig. $\mathrm{C}-4$ ).

4. Incubating the bacteria:

a. Measure $5 \mathrm{~mL}$ of autoclaved medium into a sterile plastic test tube.

b. Using a well-flamed loop, pick a colony from a \#1 or \#2 plate (figs. C-5 and C-6).

c. Open the tube and touch the end of the loop to the inside of the tube or swish the end of the loop in the broth to transfer the colony. Whichever you do, do it quickly. Get in and out of the bottle as quickly as possible (fig. C-7).

d. Label tube with the following information:

i. Bacteria strain.

ii. Today's date.

iii. Source of the inoculum (plate number and date).

e. Incubate the tube on a shaker overnight (fig. C-8). This is good for 1 or 2 days.

f. Add $5 \mathrm{~mL}$ of starting solution to each $580-\mathrm{mL}$ culture bottle and enter each inoculated bottle in the Culture Log, one line per bottle.

g. Put the bottles on the shaker, and grow the bacteria for a week.

5. Generally, inoculations will be performed as often as needed to supply a sufficient supply for the following week. These cultures will grow for a week before they are harvested.

\section{Testing Bacteria for Incomplete Conversion of Nitrate}

1. Withdraw $1 \mathrm{~mL}$ of solution from each $580-\mathrm{mL}$ culture to be harvested.

2. Add $40 \mu \mathrm{L}$ of sulfanilamide to convert $\mathrm{NO}_{3}^{-}$to $\mathrm{NO}_{2}$.

3. Add $40 \mu \mathrm{L}$ of $\mathrm{N}$-(1-naphthyl) ethylenediamine dihydrochloride (NED), which turns to pink if any $\mathrm{NO}_{2}^{-}$is present in the solution.

4. If it turns pink, it indicates that that the bacteria has not quantitatively converted $\mathrm{NO}_{3}^{-}$to $\mathrm{N}_{2} \mathrm{O}$, and the bottle should not be used until further testing shows no pink coloring. A cloudy culture should be visible after 5 days. When consumption of the $\mathrm{NO}_{3}^{-}$is complete, label the bottle as ready for use (fig. C-9). 


\section{Harvesting the Bacteria-Concentrating Culture by Centrifugation}

1. Evenly distribute $500 \mathrm{~mL}$ of culture into four $250-\mathrm{mL}$ centrifuge bottles by weighing.

2. Screw caps on tightly and put the bottles into centrifuge, making sure they balance each other (fig. C-10).

3. Centrifuge the bottles for $15 \mathrm{~min}$ at $18{ }^{\circ} \mathrm{C}$ and $3800 \mathrm{rpm}$. (Bacteria should be pelleted on the bottom of the bottle).

4. Discard clear medium supernatant, taking care not to disturb the ring of bacteria.

5. Add $15 \mathrm{~mL}$ from a $100-\mathrm{mL}, \mathrm{NO}_{3}^{-}$-free medium unit to each centrifuge bottle.

6. Swirl bottles to re-suspend the bacteria and transfer to a sterile $250-\mathrm{mL}$ beaker.

7. Use remaining $\mathrm{NO}_{3}^{-}$-free medium for rinsing all four centrifuge bottles, adding the rinse to the 250-mL beaker.

8. Add 10 drops antifoam B solution to the beaker.

\section{Adding Concentrated Cell Culture to Sample Vial and Purging Headspace and Adding Samples}

1. Dispense $3 \mathrm{~mL}$ of concentrated cell culture into each sample vial (fig. $\mathrm{C}-11$ ).

2. Using a mechanical crimper (fig. C-12), seal vials with Teflon-aluminum-lined silicone septum inserted into aluminum crimps (fig. C-13).

3. Insert a helium vent needle (1.5-in. long, 25 gauge) into vial (fig. $\mathrm{C}-14$ ).

4. Insert each vial upside down into helium purging manifold.

5. Purge vials with 3 to 4 psi helium for 1 hour (h) (fig. C-15).

6. Inject a sufficient amount of sample water to produce 5 to $20 \mathrm{nmol} \mathrm{N}_{2} \mathrm{O}$ (1 to $10 \mathrm{~mL}$ ) with an airtight syringe equipped with a 25 -gauge needle (fig. $\mathrm{C}-16$ ). If the amount of water needed is more than $4 \mathrm{~mL}$, insert a venting needle while injecting to avoid over pressurization. Mix well by inverting the vial several times.

7. Turn the vial upside down (fig. C-17) and incubate for $2 \mathrm{~h}$.

8. Samples now are ready to be loaded on the Finnigan MAT GasBench 2 (fig. C-18) for isotope analysis. Loaded samples are shown in fig. C-19. 


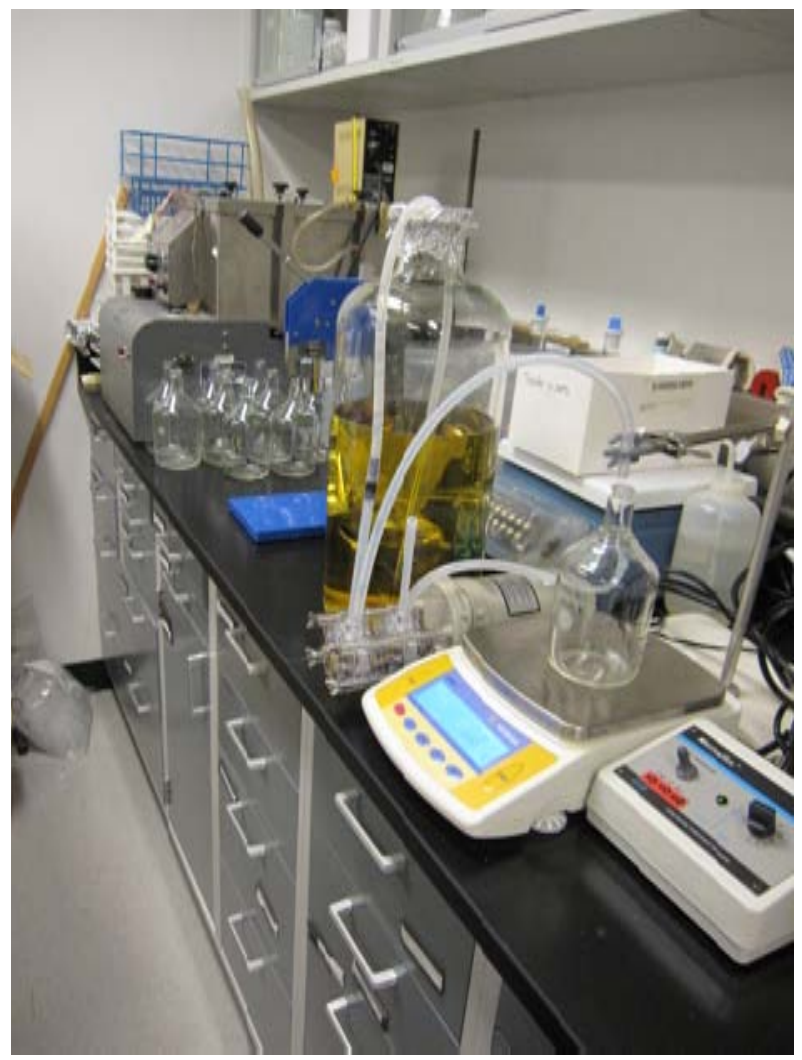

Figure C-1. Tryptic soy broth (TSB), with $\mathrm{KNO}_{3}$, prepared, mixed in 9-L bottle (yellow liquid), and divided into $500-\mathrm{g}$ aliquots.

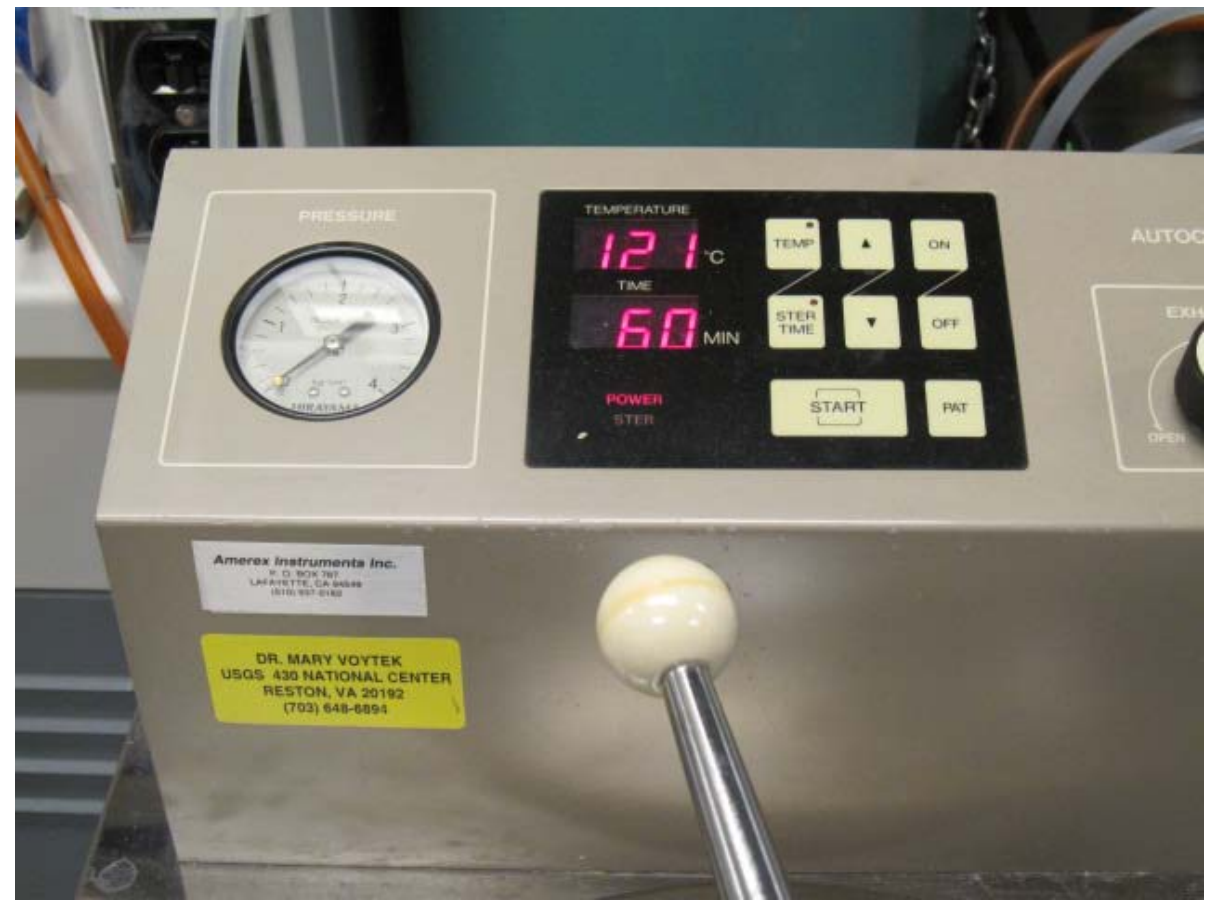

Figure C-2. Autoclaved for 60 minutes at $120^{\circ} \mathrm{C}$. 


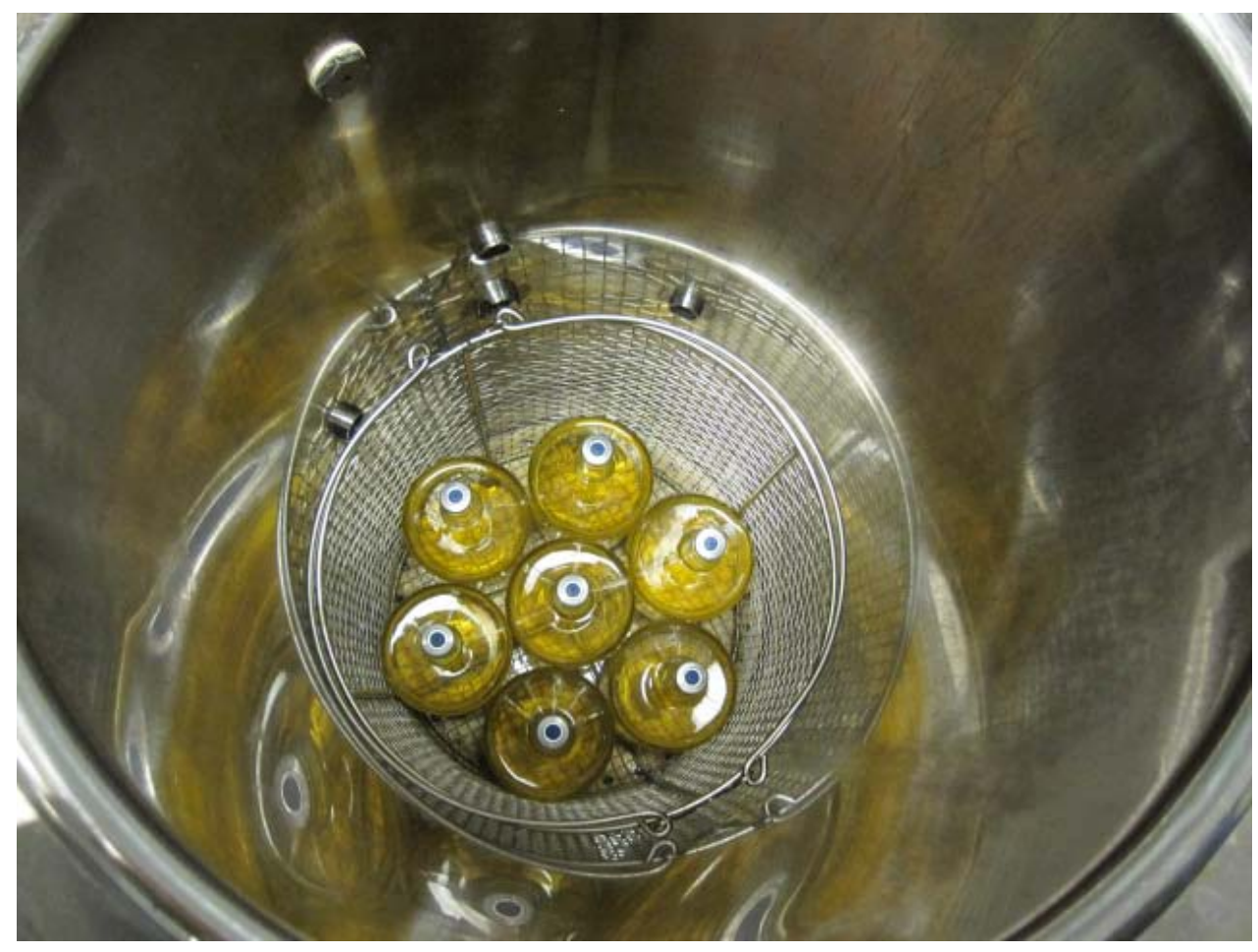

Figure C-3. Top view of 580-mL bottles with media ready to be autoclaved.

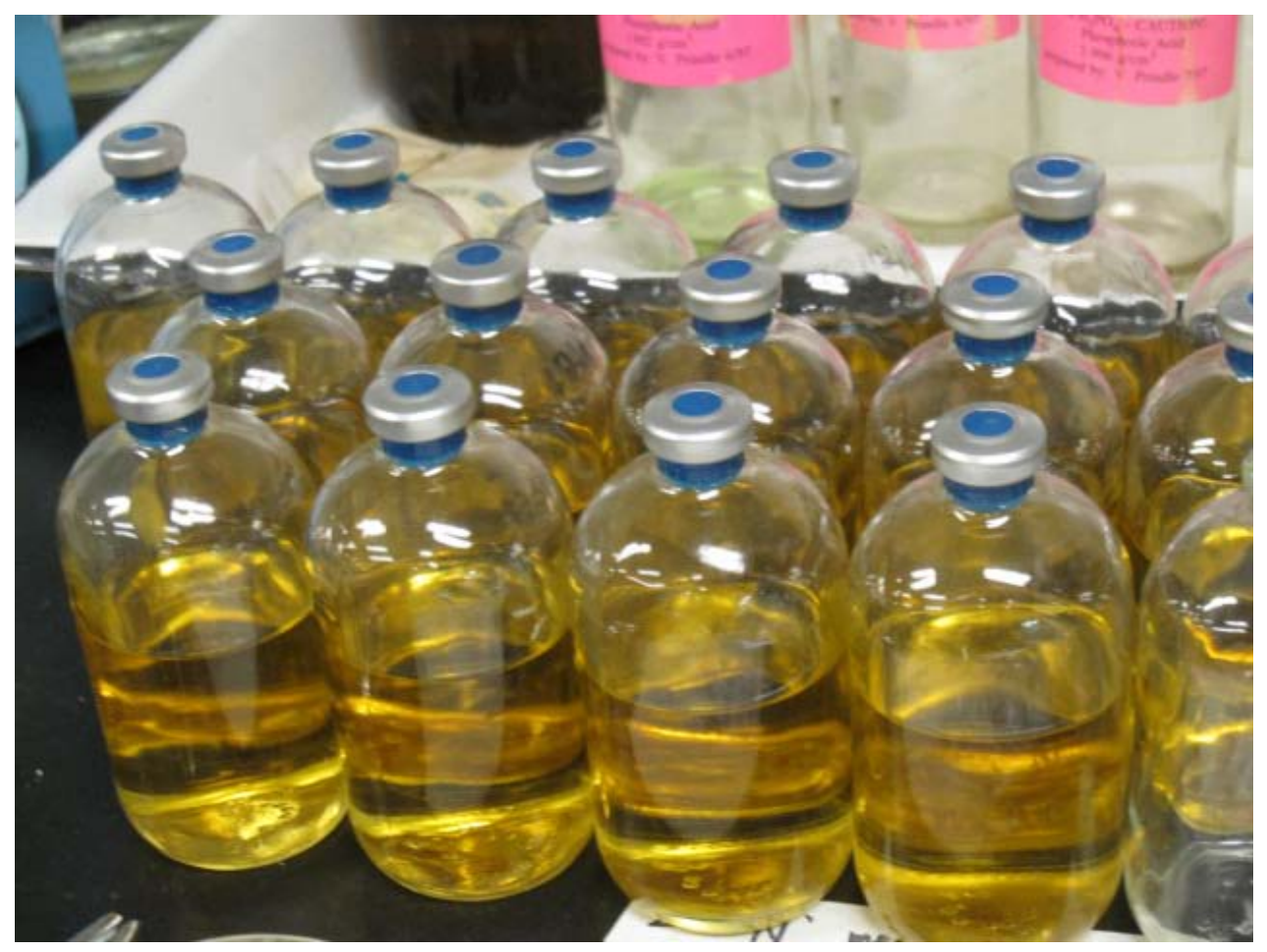

Figure C-4. Tryptic Soy broth (TSB) without $\mathrm{KNO}_{3}$, prepared with $100-\mathrm{mL}$ aliquots in $125-\mathrm{mL}$ serum bottles. 


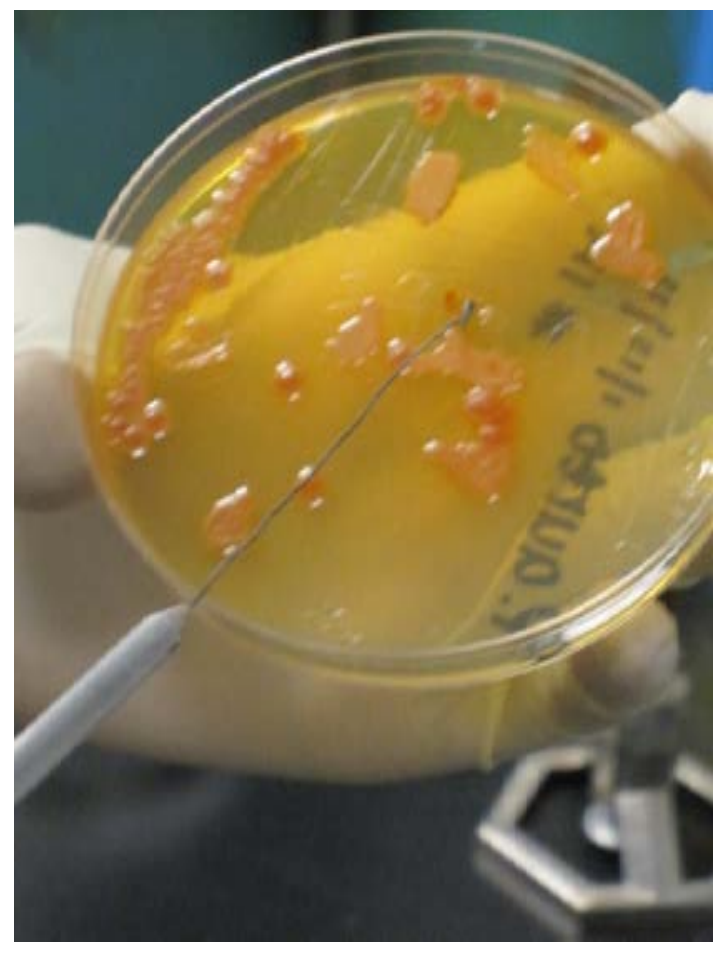

Figure $\mathbf{C}-\mathbf{5}$. Selecting a separate colony from the plate using a sterile flamed loop.

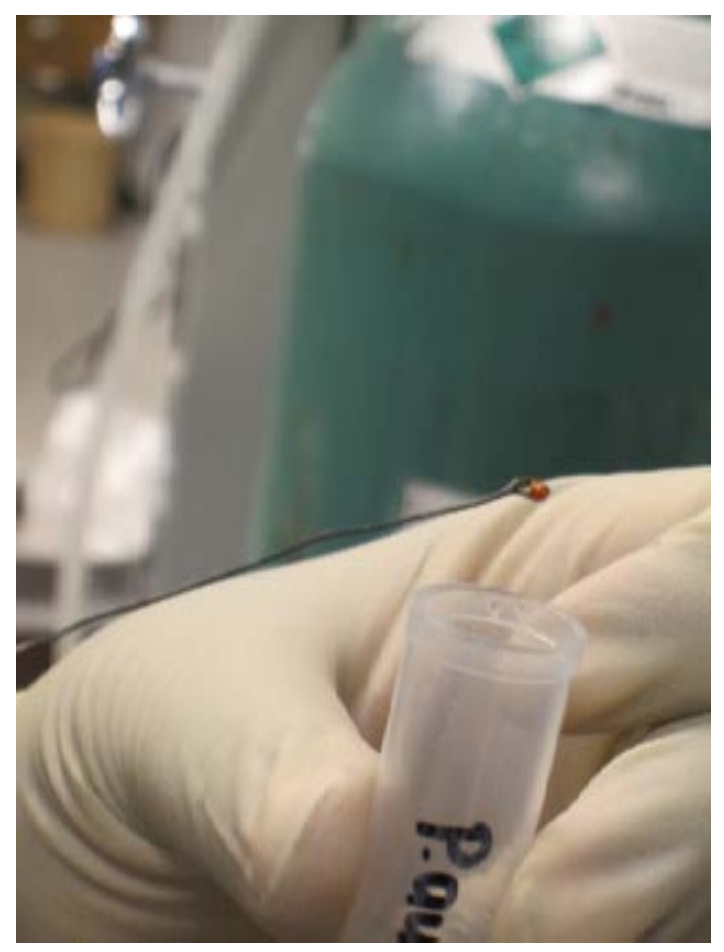

Figure C-6. Selected colony is shown. 


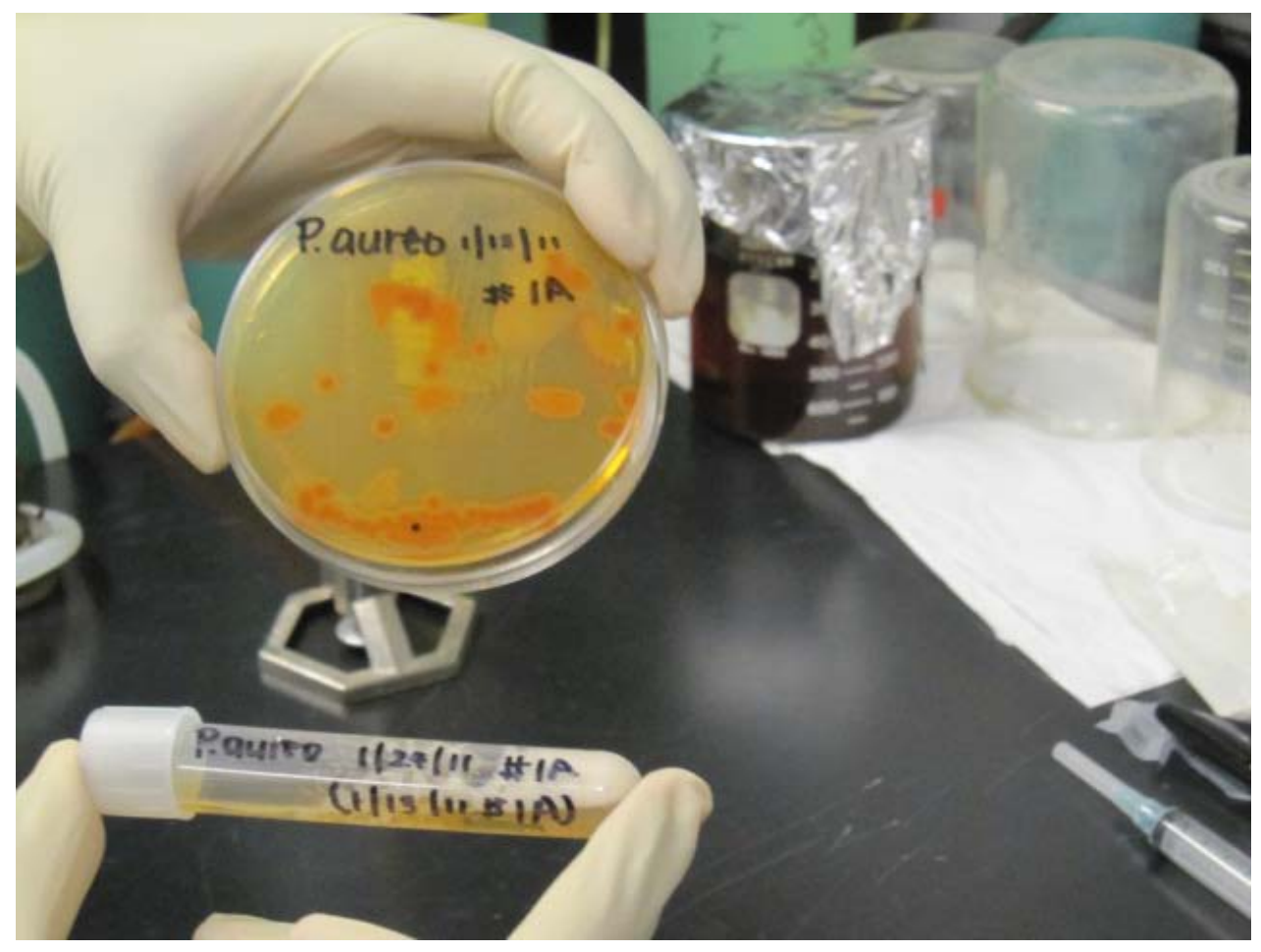

Figure C-7. Selected colony transferred to labeled tube containing $5 \mathrm{~mL}$ of TSB.

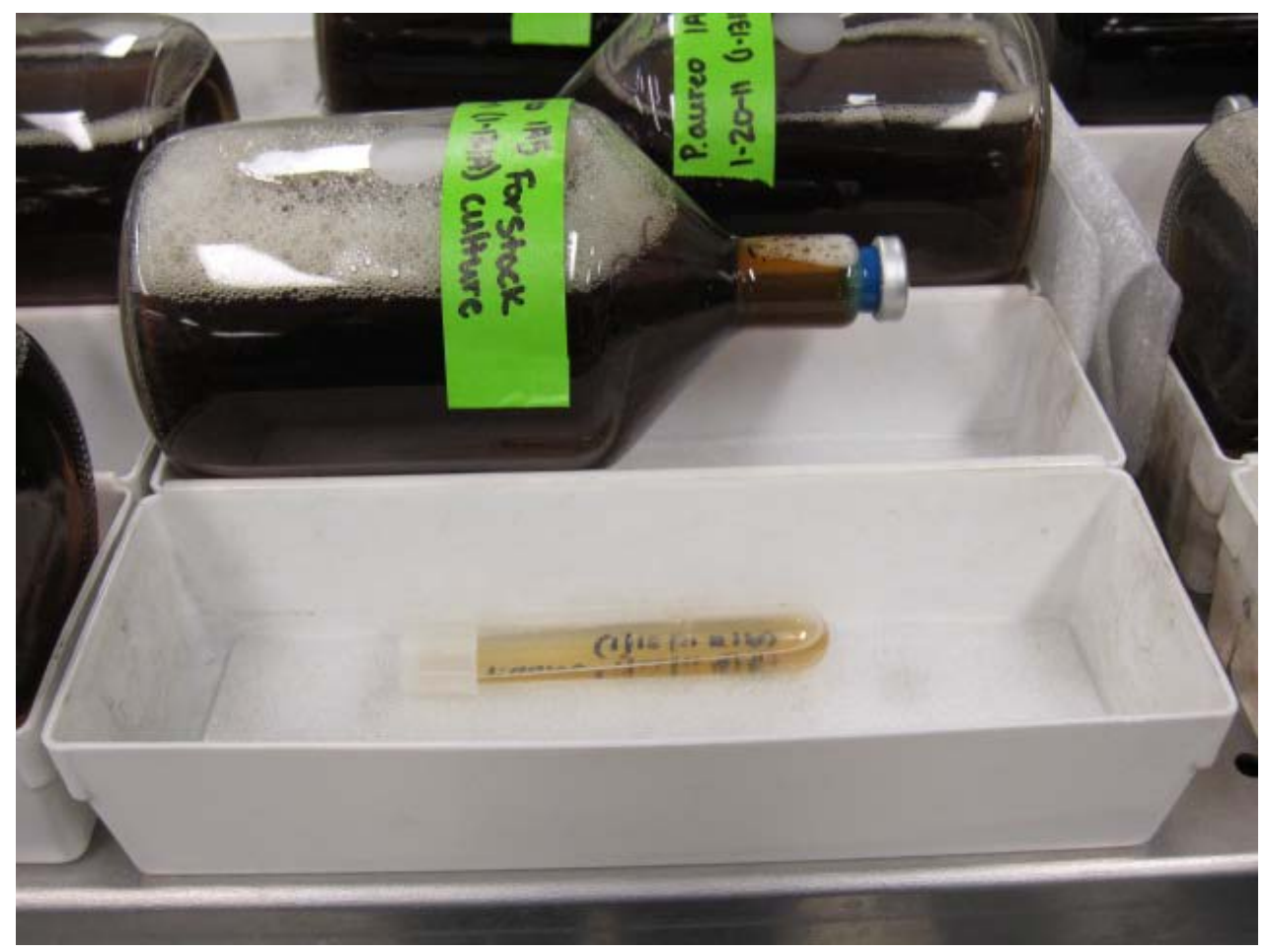

Figure C-8. Shaker showing $5 \mathrm{~mL}$ of culture before injection and showing previously prepared $580-\mathrm{mL}$ bottles injected with bacteria. 


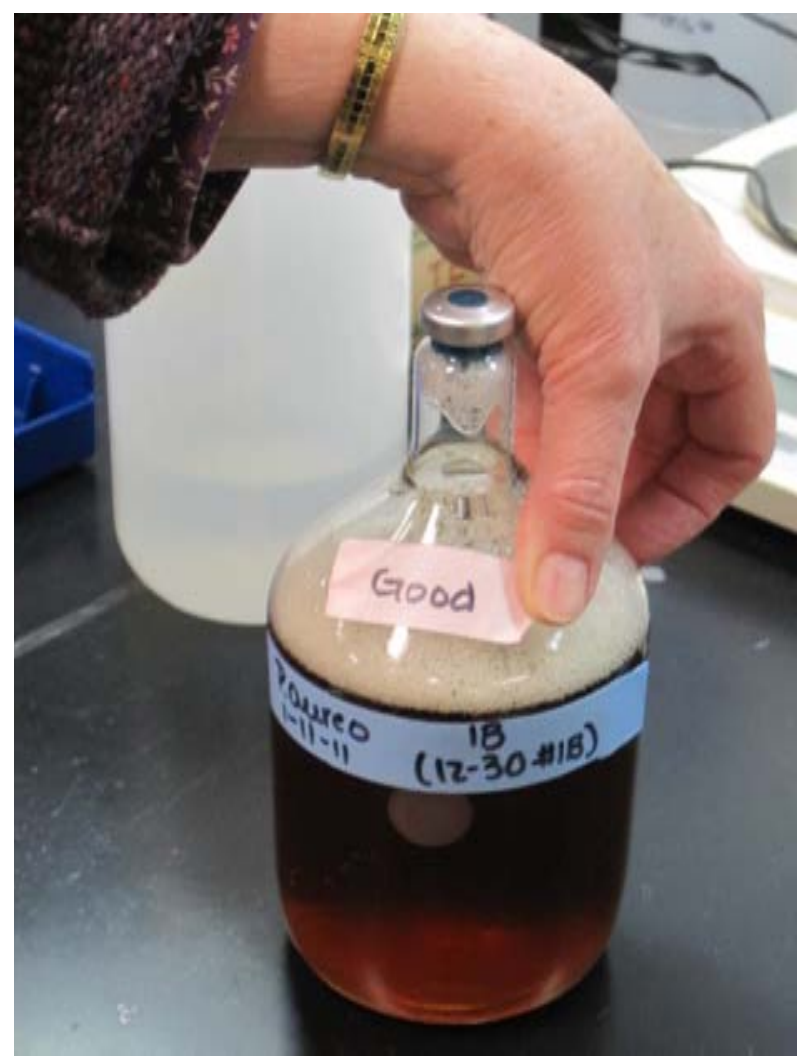

Figure C-9. A bottle of nitrate-free bacterial culture ready for use.

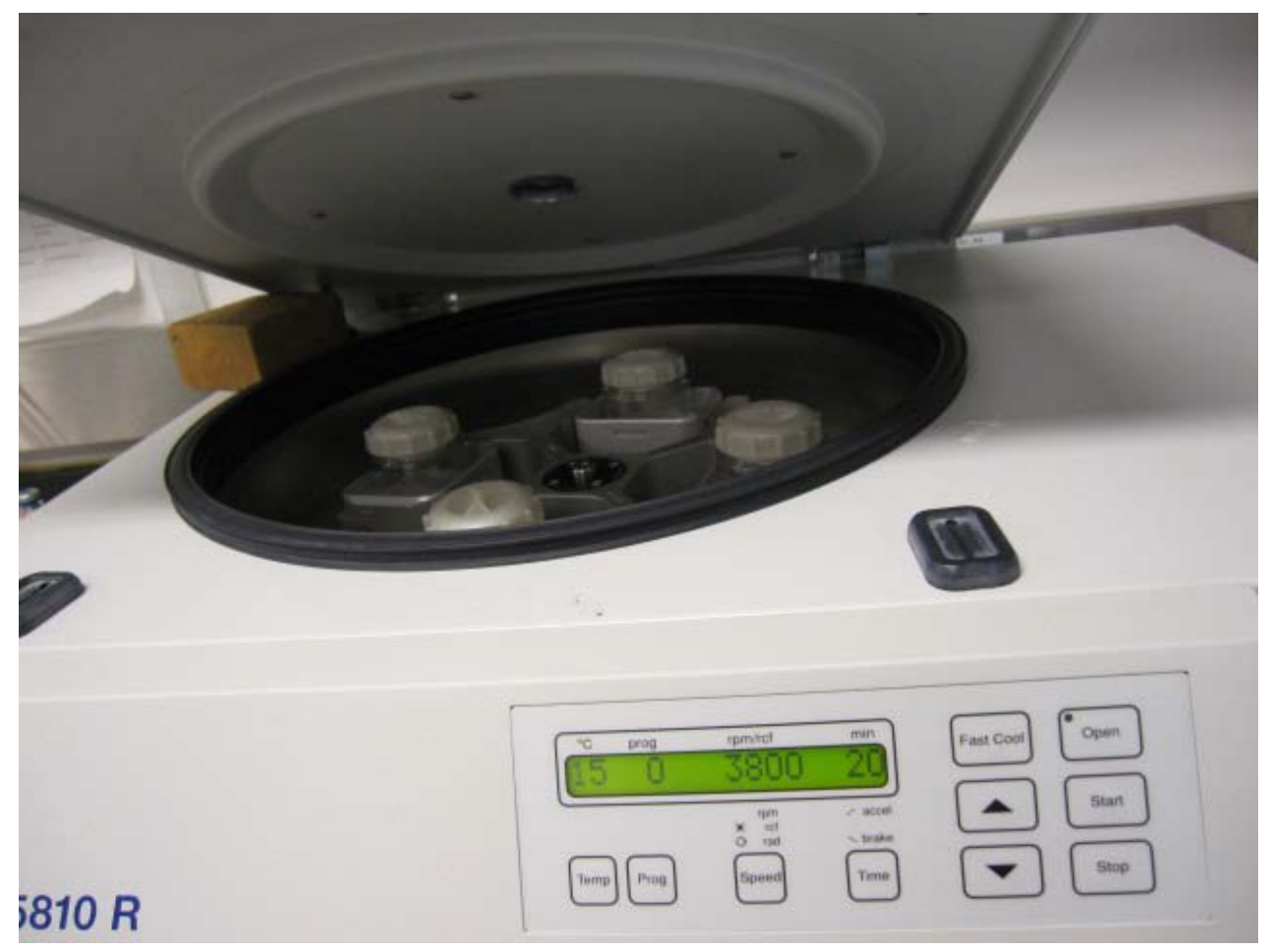

Figure C-10. Centrifuge with four $250-\mathrm{mL}$ bottles. 


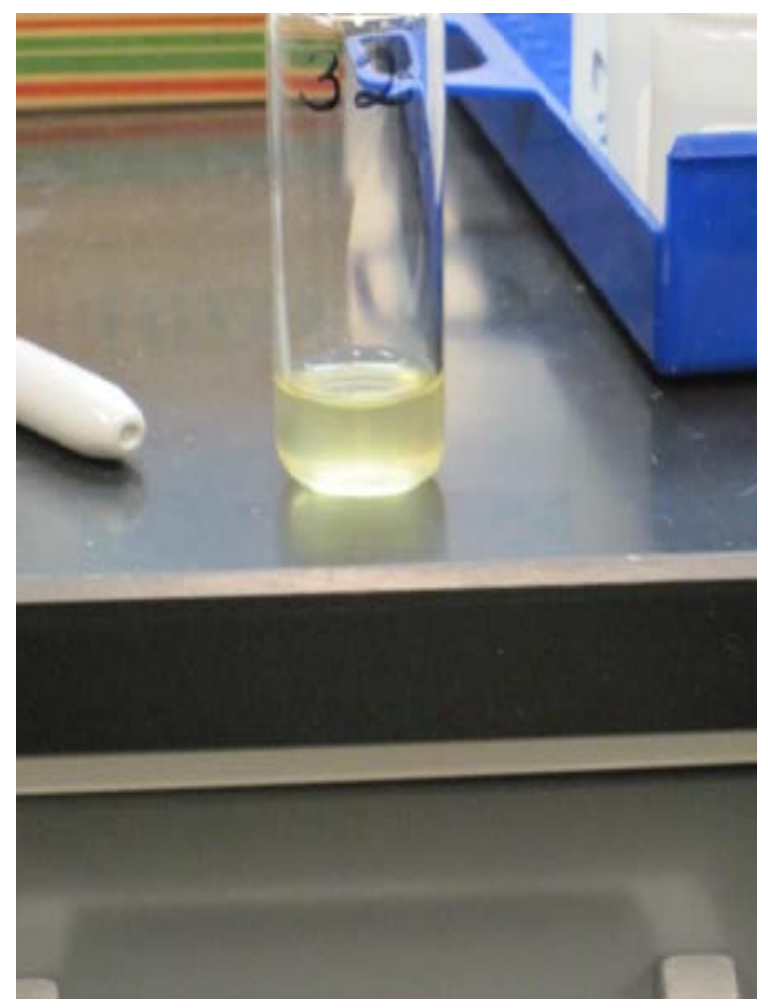

Figure C-11. Twenty-milliliter sample vial containing $3 \mathrm{~mL}$ of concentrated cell culture.

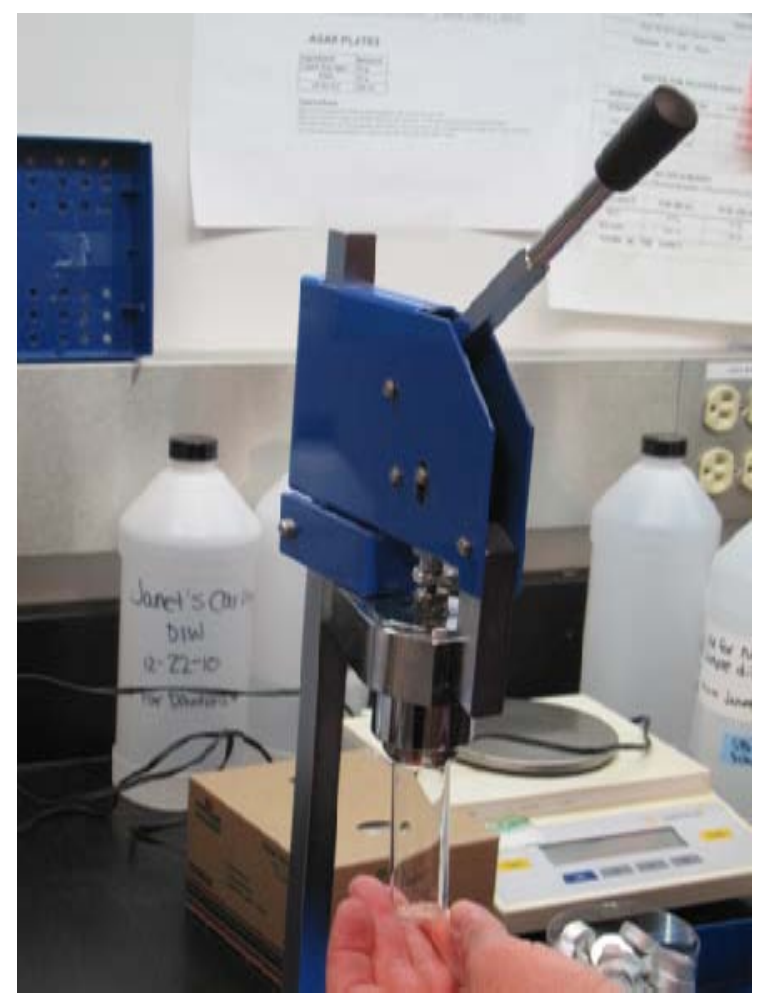

Figure C-12. Mechanical crimper. 


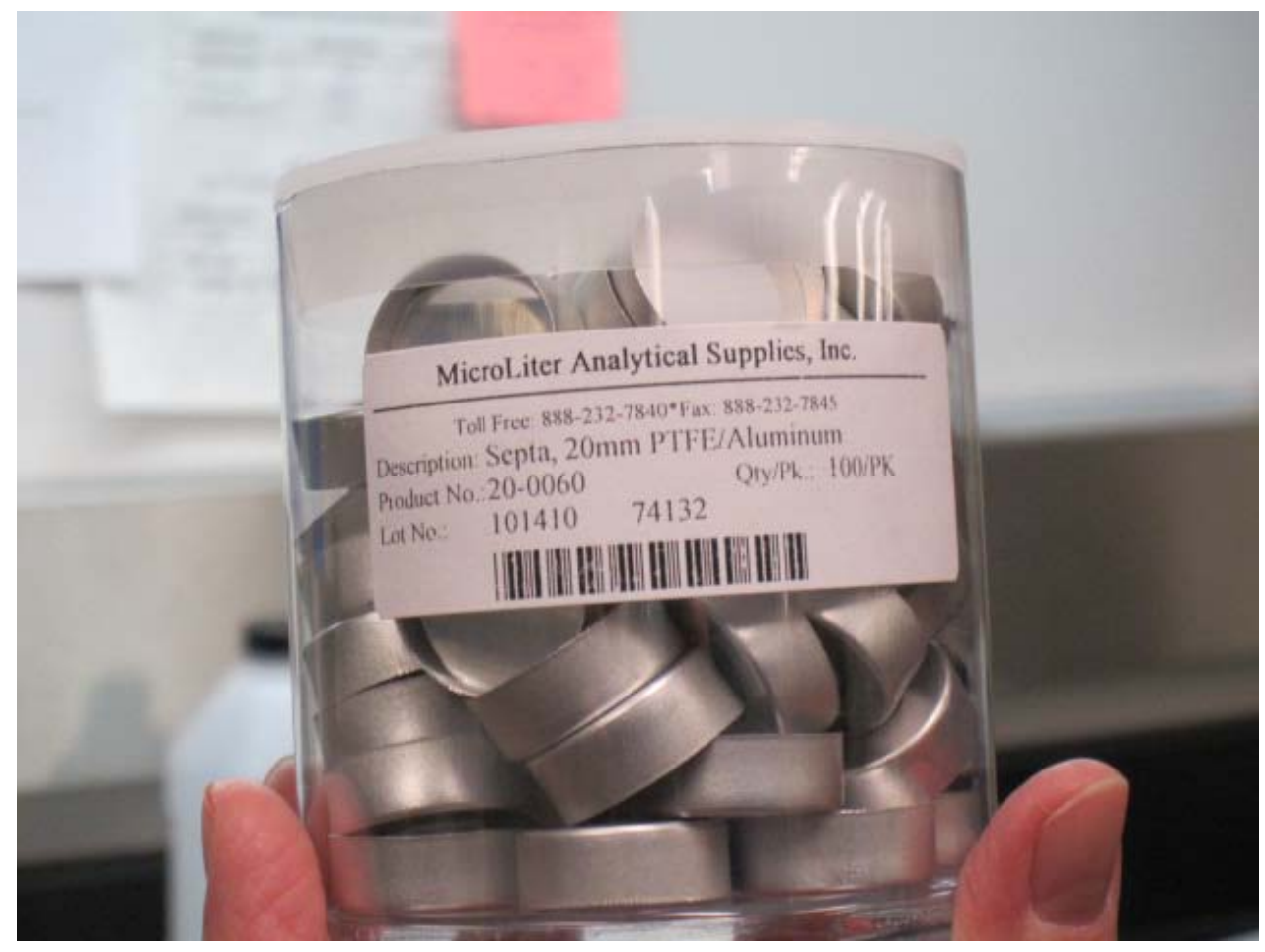

Figure C-13. PTFE/Aluminum-lined septa with aluminum crimps.

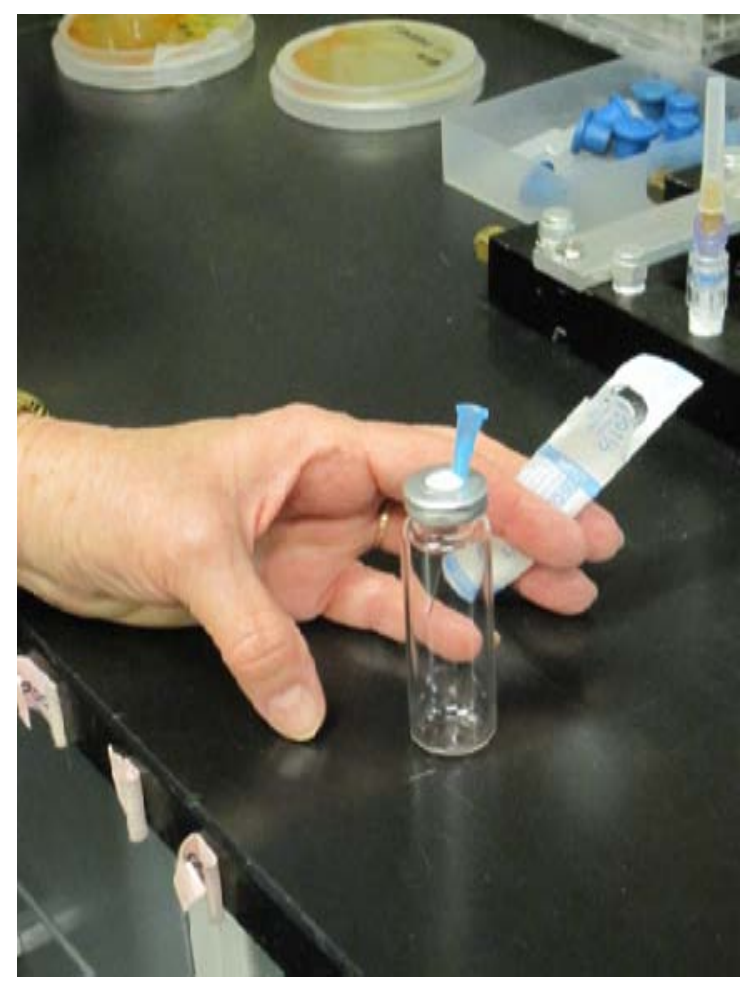

Figure C-14. Empty vial showing placement of vent needle. 


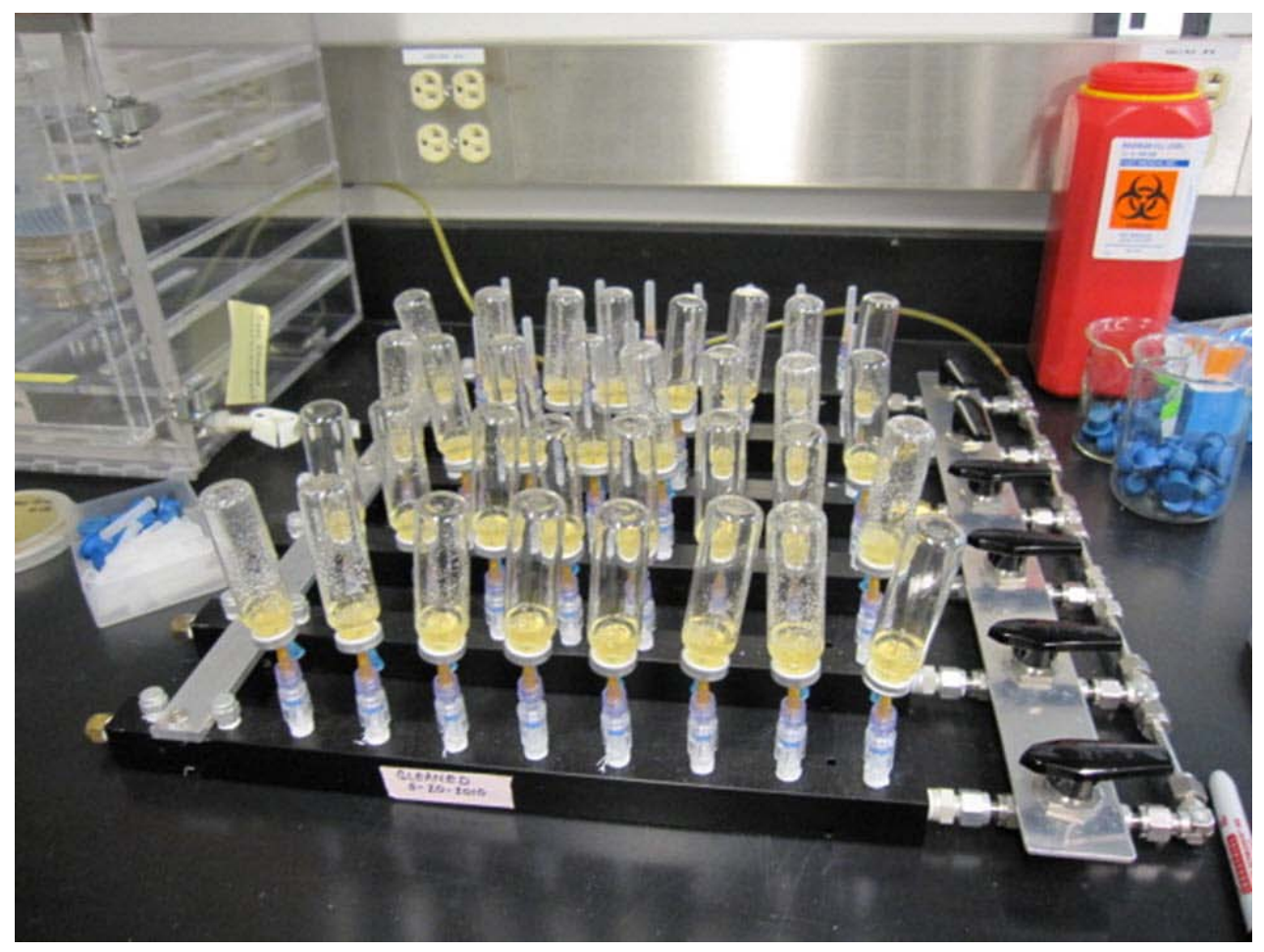

Figure C-15. Manifold showing helium purging of 32 vials.

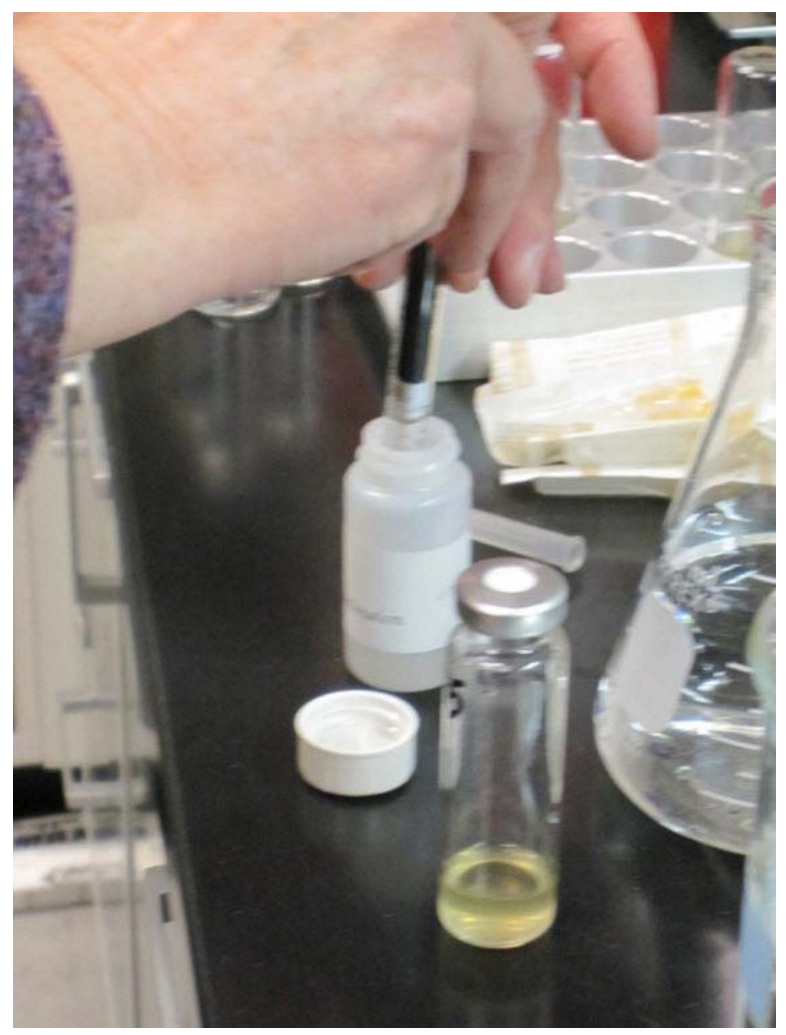

Figure C-16. Loading vial with sample. 


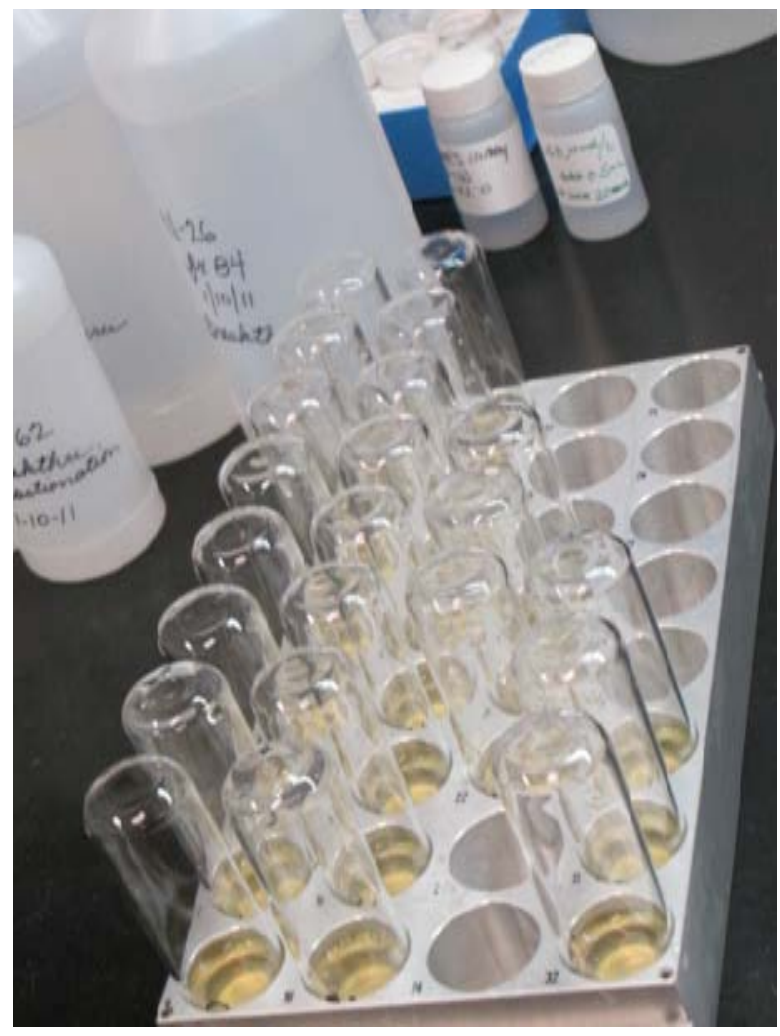

Figure $\mathbf{C}-17$. Aluminum tray with inverted sample vials.

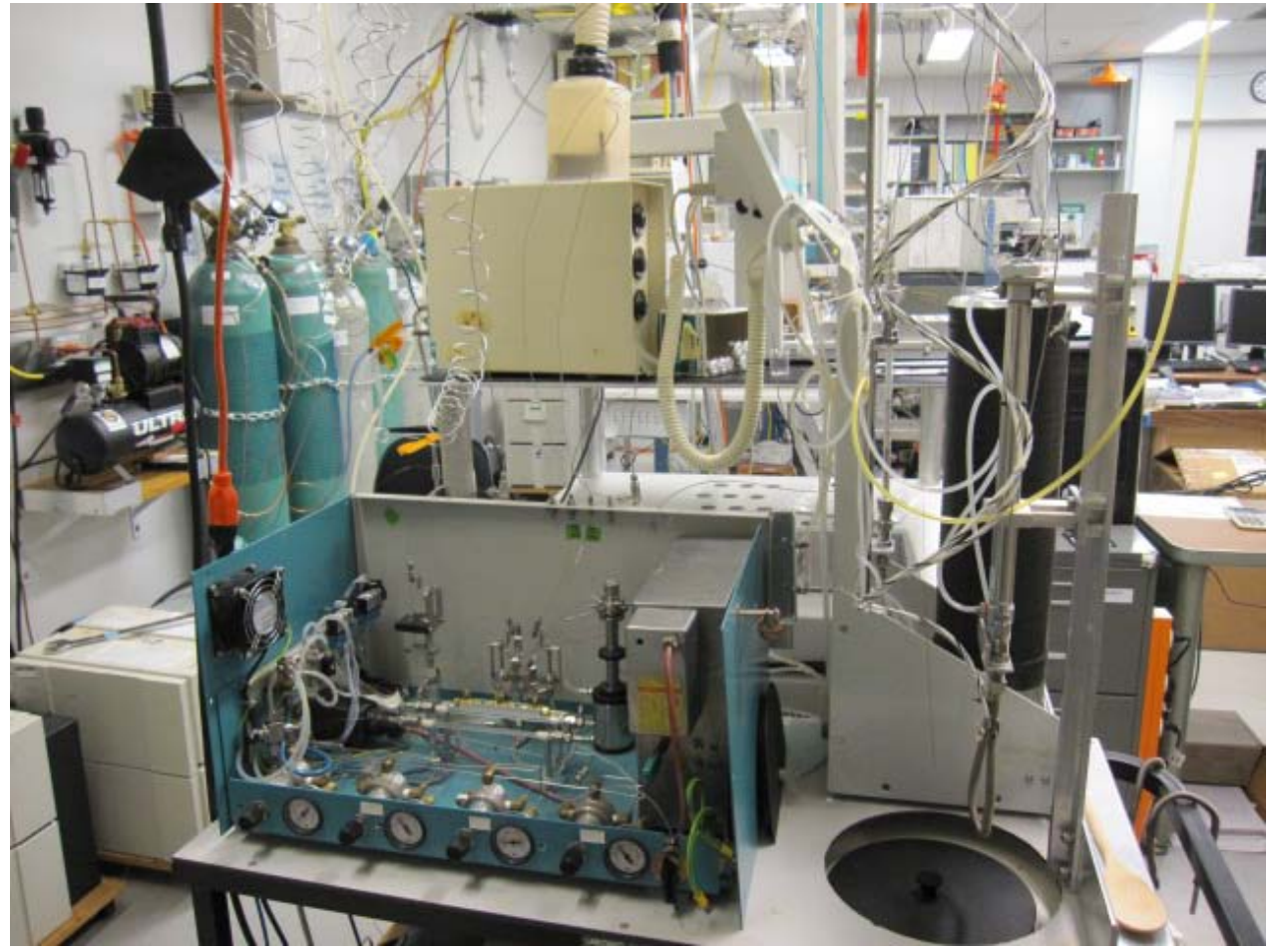

Figure C-18. Finnigan MAT GasBench 2. 


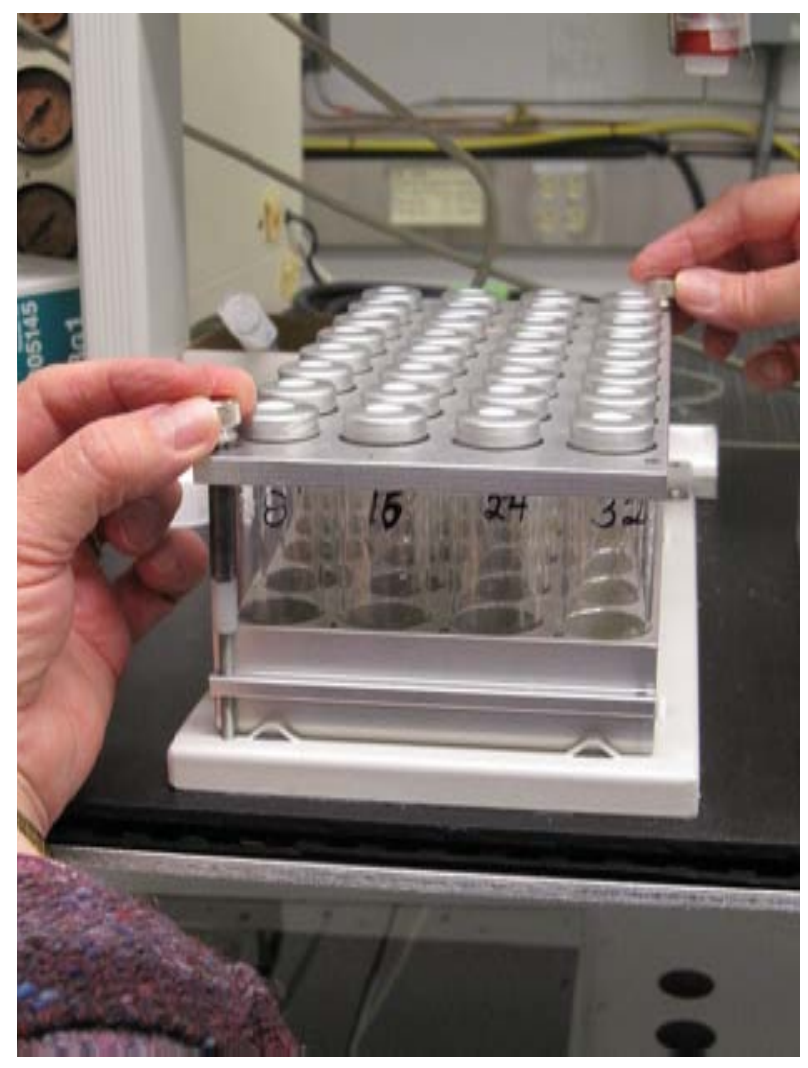

Figure C-19. Sample tray with 32 vials and a 1/4-inch-thick aluminum plate to secure vials. 


\section{Appendix D. Step-by-Step Procedure to Add Sample Information to Sequence Table}

1. Insert the diskette with sample headings generated by LIMS-LSI.

2. Open sequence table in Excel.

3. Open " $\mathrm{N}_{2} \mathrm{O}$ Sample Sequence File” under the GB configuration.

4. Copy the sequence template from Excel and paste it to sequence table of the mass spectrometer's data acquisition and control computer.

5. Select the appropriate "method" for each sample.

6. Define a reference line and blank line (as needed).

7. Start.

8. Give Folder Name: Comment.

a. Select pre: "Date."

9. Give File Name: leave it empty.

a. Select pre: "Analyzes \#."

b. Select post: "Identifier 1."

c. Select: "Print Result."

10. Click OK.

11. Wait for first sample to be analyzed. 


\section{Appendix E. Step-by-Step Procedure to Transfer Data to LIMS-LSI, to Transfer Data to Back-Up Computer, and to Reevaluate Old Data}

1. Transfer data to LIMS-LSI:
a. Start LIMS.
b. Choose "Import Data From Instruments."
c. Choose mass spectrometer, for example "H --> Hercules.”
d. Click "Import."
e. Select the file that will be imported. columns containing the isotope data. Enter column names as appropriate for the isotope or isotopes to be imported.
f. Depending upon the mass spectrometer, the user may be given the opportunity to select the
g. Click “Import.” Note: Sample ID, sample weight, Peak Area, Analyses \#s are automatically imported to LIMS-LSI.

2. Transfer data to Data Back-Up computer:
a. Go to Windows Explorer in the Data Back-Up computer.
b. Find the drive where your back ups are stored.
c. Choose: "RSIL."
d. Choose: "Mass. Spec. Analysis Back Up.”
e. Choose the mass spectrometer. For example, "H," which stands for "Hercules," a Thermo Scientific Delta V Plus IRMS.
f. Under that folder create a new folder. The name of the folder should be the date range of the analyses that one wishes to back up.
g. Transfer data to that folder.
h. Make back ups every 2 weeks or so, as needed.

3. Reevaluate old data:
a. Find your samples in the Data Back-Up computer.
b. Transfer data by a memory stick to the computer where a virtual version of ISODAT 2.0 is installed.
c. Reevaluate your data. 


\section{Appendix F. Step-by-Step Procedure to Determine and Apply Correction Factors and Evaluate Data}

1. Open "Apply Data Normalization” in LIMS-LSI.

2. Select instrument and isotope, for example "H (Hercules) for 34S."

3. Select "Query."

4. Double click on the last sample analyzed on that day.

5. Evaluate data of the reference materials.

6. Choose "Normalize with all References."

7. Click “Apply Normalization -->.”

8. Print out correction factor sheet.

9. Report daily reference values and correction factors along with date and range of analysis number to the "EA" binder.

10. Go back to LIMS-LSI main menu by closing open windows.

11. Choose "Print/Save Analyses in Progress":
a. Choose appropriate isotope.
b. Choose appropriate prefix ( $\mathrm{W}$ for water, $\mathrm{N}$ for nitrogen, $\mathrm{S}$ for sulfur).
c. Enter sample ID range from "Samples-to-Be-Analyzed" sheet.
d. Click Print.

12. Review results and identify samples that need to be re-analyzed.

13. Add the samples needing analyses to the Samples to Be Analyzed:
a. Go back to LIMS-LSI main menu.
b. Open "Create a Sample List -->."
c. Select appropriate sample list for the mass spectrometer and the samples that are to be analyzed.
d. Find each sample in the "List of samples."
e. Change entry in "Repeats" column from 0 to 1.
f. Close Windows and exit LIMS-LSI. 


\section{Appendix G. Daily Check List}

Analyst in charge:

Date:

1. Change the working reference gas tank and helium gas tank if the pressure is $<500$ psi. Order new ones for spares; the reference gas is research grade, helium; the carrier gas is zero grade.

2. Change the Nafion every 10 months, and change the water and $\mathrm{CO}_{2}$ trap every 1 to 2 months.

3. Replace isopropanol-slush trap daily. Clean the used trap with ethanol and DIW, and dry it in a $150{ }^{\circ} \mathrm{C}$ oven.

4. Clean the sample-transfer line (1/32-inch diameter stainless steel tubing) between the needle and the isopropanol-slush trap every 6 months by injecting ethanol and DIW.

THESE ITEMS ARE TO BE CHECKED OFF AS YOU CHECK THEM DAILY!

1. Check the helium and reference gas flow. [ ]

2. Check the background masses. [ ]

\begin{tabular}{|c|c|c|c|c|c|c|}
\hline Cups & Mass & Intensity (V) & Mass & Intensity (V) & Resistor ( $\mathbf{\Omega})$ & Capacity (pF) \\
\hline 1 & 28 & 0.007 & & 0 & $3 \times 10^{8}$ & 680 \\
\hline 2 & 29 & 0.003 & 18 & 1.256 & $3 \times 10^{10}$ & 5 \\
\hline 3 & 30 & 0.083 & 18 & 6.818 & $3 \times 10^{11}$ & 2 \\
\hline
\end{tabular}

3. Check the peak center. [ ]

4. Analyze the Ref on/off method 10 times to stabilize the IRMS (STD should be $<0.1 \%$ ). [ ]

\begin{tabular}{|l|l|}
\hline $\begin{array}{c}\text { ConFlo II Pressure Setting } \\
\mathbf{N}_{2} \mathbf{O} \text { (bar) }\end{array}$ & \multicolumn{1}{|c|}{$\begin{array}{c}\mathbf{N}_{\mathbf{2}} \mathbf{O} \text { signal (V) Mass 45 on } \\
\text { Cup 2 }\end{array}$} \\
\hline 0.25 & 0.638 \\
\hline 0.50 & 1.59 \\
\hline $\mathbf{0 . 7 5}$ Optimal setting & $\mathbf{2 . 6 5 3}$ \\
\hline 1.00 & 3.921 \\
\hline 1.25 & 5.315 \\
\hline 1.50 & 7.059 \\
\hline 1.75 & 8.778 \\
\hline 2.00 & $>10.8$ \\
\hline
\end{tabular}

5. Record the analysis date, the project, the sample submitter, and the mass spectrometer analysis number in the electronic lab-log book (in xls format). Also record the instrument working status. 


\section{Appendix H. Step-by-Step Procedure to Report Data}

1. Open "Store Samples in Progress" in LIMS-LSI.

2. Choose the appropriate isotope.

3. Choose sample ID range from "Sample in Progress" print out.

4. Store data.

5. Go back to the main menu of LIMS-LSI.

6. Open "Project" and find the appropriate project in the list.

7. Select "Print Report" and check whether the project report contains all the results. If not, search for the missing results in the database.

8. Select "Results," transfer data in Excel format or (and) text format to a diskette, and report data to customer through e-mail.

9. Click "Print Report” to print a project report and put it in the "Correspondence” binder along with all the other documents in the "Samples In Progress" binder that are related to this project. 